\title{
IMMUNO-HISTOMORPHOMETRIC STUDIES AND THE EFFECT OF SOME ANTIBIOTIC ALTERNATIVES ON SHE-CAMEL STAPHYLOCOCCUS MASTITIS
}

\author{
HANAA A. EL-HALLAWANY ${ }^{1}$; HANAA A.E. ASFOUR ${ }^{2}$; INAS M. GAMAL ${ }^{3}$ \\ AND SHEREEN S. EL-MOHANDES ${ }^{4}$ \\ ${ }^{1}$ Pathology Department, Animal Reproduction Research Institute (A.R.R.I.), Giza, Egypt. \\ ${ }^{2,4}$ Mastitis and Neonatal Diseases Department, Animal Reproduction Research Institute (A.R.R.I.), Giza, Egypt. \\ ${ }^{3}$ Immunology and Immunopharmacology Unit, Animal Reproduction Research Institute (A.R.R.I.), Giza, Egypt.
}

Received: 31 March 2018; Accepted: 30 April 2018

\begin{abstract}
Bacteriological examination of 50 she camel's udder tissue samples collected from different slaughter houses revealed that Staphylococcus spp. were the most common isolated bacteria $(90 \%)$ as single and mixed infection followed by environmental Streptococcus spp. (40\%) then E.coli (26\%) in the form of mixed infection. Most of the isolated S.aureus and coagulase negative staphylococci (CNS) were resistant to 14 commercially available antibiotic discs. By using 4 antimicrobial peptides (AMPs) as alternatives to antibiotics; included lysozyme (Lz), lactoferrin (Lf), serum amyloid A (SAA) and haptoglobin (Hp) the results revealed only Lz and Lf have antibacterial activities for both S.aureus and CNS isolated from the udder tissues while SAA and $\mathrm{Hp}$ did not show antibacterial effects for the tested strains. By using combinations of the different antibiotics and the four AMPs we noticed significant synergistic effect for all of them on the tested strains. Analysis of protein profile of the infected udder tissue samples with both S.aureus and CNS using SDS-PAGE used to evaluate the immunological status of the naturally infected she camel mammary tissue samples with S.aureus or CNS in comparison to bacteriologically negative mammary tissue samples and the results cleared that the concentrations of Lz, Lf, $\mathrm{Hp}$ and mSAA were significantly higher in tissue samples infected with both S.aureus and CNS when compared with the non-infected tissue samples. While the concentration of Lf showed a significant rise in tissue samples infected with CNS when compared with tissue samples infected with $S$. aureus. UPGMA clustering dendrogram analysis was applied to compare the protein fingerprints of the isolated Staphylococcus spp. and illustrated that there were no or weak similarities in the protein fingerprints of the different isolated S.aureus and CNS strains ranging from $(0-0.36)$. In the present study, histopathological changes in singly isolated S.aureus mastitic tissue sections revealed grossly, varied degrees of congestion with oedema in $19(38 \%)$ of the mammary tissue samples which represented 7 tissue samples of acute diffuse mastitis (14\%) only 2 of them showed suppuration and 12 cases (24\%) subacute interstitial mastitis and the majority of tissue samples 26 (52\%) showed fibrosis and paleness. On the other hand, microscopically exhibited severe histological changes which varied from epithelial degeneration, alveolar atrophy and necrosis, in the acute and sub-acute suppurative inflammatory response marked by neutrophil infiltration, congestion, to increased stromal tissue (fibrosis) and presence of non-suppurative inflammation marked by lymphocytic infiltration in alveoli with disappearance of the alveolar lumen, through fibrosis to the complete destruction of the parenchyma in chronic mastitis which was the most majority noticed type of mastitis was chronic non suppurative mastitis. Histochemicallly, interstitial, perialveolar, intra and inter acinar fibrosis were confirmed with Masson's Trichrome stain as greenish blue fibres. The activity of alkaline phosphatase in tissue sections of non mastitic animals showed high secretory activity on the outer boundary of alveolar secretary cells. While, tissue sections taken from $S$. aureus singly infected mastitic animals showed weak alkaline phosphatase activity (AP), on the outer membrane and weak protein expression by protein loci (mercury-bromophenol blue) comparing to the non-mastitic once. On the other hand histomorphometrically, tissue sections from singly infected S. aureus showed $(\mathrm{P}<0.05)$ significant decrease in alveolar diameter, number of alveoli and alveolar cell population whereas the interstitial connective tissues showed $(\mathrm{P}<0.05)$ significant increase compared to the non mastitic tissue. We concluded that, Staphylococci were the major bacteria causing mastitis in she camels and showed great differences in their protein profiles, consequently caused significant increase in the inflammatory responses of the udder tissues represented by the increase of Lz, Lf, SAA and Hp concentrations in the tissues. Staphylococci as single infection enough for inducing sever degenerative changes and damage that reflecting impaired activity as well as printed on the different histopathological, histochemical and morphometric changes in she camel's mammary parenchyma. Furthermore, this study offers opportunities for development of treatment strategies that may eliminate or even reduce mammary tissue damage caused by Staphylococcal mastitis with or without the use of antibiotics and/or anti-inflammatory molecules like Lz, Lf, SAA and Hp.
\end{abstract}

Key words: She camel; mastitis; Staphylococcus spp; antibiotic/antibiotic alternatives (Lz, Lf, SAA, Hp) sensitivity; immunology; histopathology; histochemistry; histomorphometrical changes.

Corresponding author: Dr. HANAA A. EL-HALLAWANY E-mail address: hanaeg2002@yahoo.com

Present address: Pathology Department, Animal Reproduction Research Institute (A.R.R.I.), Giza, Egypt.

\section{INTRODUCTION}

The camel (Camelus dromedaries) is the most dominant and widely distributed animal in Africa and Asia. It makes an important contribution to human survival and utilization in dry and arid land (Husein et 
al., 2013). Also, they are considered as wealth investment and insurance against natural disasters. It is a multipurpose animal kept for milk and meat production as well as transportation. Milk of camel is one of the main components of the diet of the nomads and is consumed in its raw or naturally processed (soured) form as it could meet a big part of the daily needs of humans from nutrients (Al-Otaibi and ElDemerdash, 2013).

Udder infection was considered as one of the main constraints for camel rearing. The major pathogens isolated from udder tissues of she camels were S.aureus, S.agalactiea, S.uberis, E.coli, Klebsiella, Micrococcus spp., Corynebacterium and A.pyogens (Abdelgadir, 2014; Iyer et al., 2014 and Abeer et al., 2016). Despite advances in diagnosis and management practices aimed at reducing the incidence of ruminant mastitis associated with the contagious pathogens, S.aureus is one of the major contagious causative agents of clinical and subclinical mastitis that tend to become chronic and difficult to be eradicated by conventional antimicrobial therapies worldwide causing significant economic loss to the dairy industry (Sears and McCarthy, 2003; Pereira et al., 2011 and Tiwari et al., 2013). Once the intramammary infection is established, the organism adheres to epithelial cell receptors for bacterial adhesions resulting in the production of virulence factors and intracellular uptake of the small colony variants of $S$. aureus. Damage to the mammary gland epithelial lining is initiated by ulceration and occlusion of lactiferous ducts, alveoli and infiltration of inflammatory cells in the parenchyma. Mammary tissue damage is further compounded by various toxins and extracellular enzymes produced by S.aureus (Zhao and Lacasse, 2008; Middleton, 2013 and Foster et al., 2014).

Antimicrobial peptides (AMPs) exhibit a broad range of activities against Gram-negative and Grampositive bacteria, fungi, viruses, and parasites. To date, 2645 AMPs from various sources have been listed in "The AMPs Database" (Wang et al., 2009), a database dedicated to natural AMPs. This rich source of antimicrobial agents has aroused growing interest, especially in the light of the decreasing effectiveness of antibiotics not only against severe infections, but also in treating common infectious diseases. Resistance to antibiotics has become a threat to global public health and is driving novel research into the development of new antimicrobial agents (Laxminarayan et al., 2013).

Recently camel milk was used in some parts of the world to cure certain diseases (Attia et al., 2001) such as treatment of food allergies, Crohn's disease, autism and diabetes (Shabo and Yagil, 2005), as camel milk is rich with several proteins that are well known of their innate immunity activities. The most important of these proteins are Lf, Lz and Hp (Alluwaimi et al., 2017). The antibacterial and antiviral activities of the Lf were widely recoded as it exerts its effect by depriving pathogen utilization of iron by depletion. Also, Hp acts as an antioxidant, has antibacterial activity. Lysozyme has antibacterial properties against gram-positive and gram-negative bacteria (ElWassell, 2000; Masschalck and Michiels, 2003 and Agamy, 2009). Moreover, the estimation of MAA concentration in milk is a more useful diagnostic tool to monitor the udder health in dairy cattle (Hany et al., 2018).

Innovation is needed not only for the development of new antibiotics but also for combination therapies. By targeting different mechanisms of resistance simultaneously, combination therapy might help slow the emergence of resistance (Gill et al., 2015). So, combinations of milk AMPs with a greater number of antimicrobials have to be tested, as they provide new directions to control pathogens growth. Further, systematic evaluations on in-vivo models, selecting different pathogens, pathologies and administration routes should be welcomed. Another important issue is the cell-penetrating potential of AMPs as vectors for intracellular targets (Durzýnska et al., 2015).

In this study and for previous causes special care must be applied for camel's mammary gland tissues to produce clean milk, also an attempt was made to use natural antibacterial proteins as Lz, Lf, Hp and SAA that can be extracted from milk to be used as alternatives to antibiotics to avoid many problems, such as antibiotics resistance and residues, hypersensitivity, direct toxicity, antibiotic- induced immune-suppression and super-infections as camel milk is used as therapeutic agent for treatment of many human dangerous diseases.

\section{MATERIALS AND METHODS}

A- Mammary gland tissue samples collection: Fifty tissue samples from she camel's mammary glands were randomly collected from adult slaughtered animals, from Cairo and Giza abattoirs and were visually examined for gross lesions. Then each tissue sample was divided into three parts, one part was put in a small polyethylene bag in an ice box under aseptic conditions for bacteriological examination. The second part was immersed in $10 \%$ neutral formalin solution for histopathological evaluation. The third part used for immunological examination.

\section{B- Microbiological examinations:}

1- Bacteriological examination: - Mammary gland tissues were cultured on blood agar media, Mannitol salt agar, Edward's medium, MacConkey's agar plates and brain heart infusion agar media then incubated at $37^{\circ} \mathrm{C}$ for $24-48 \mathrm{hrs}$. Suspect colonies were examined for colony morphology, Gram stain 
characteristics and motility. Gram negative bacilli and Gram-positive cocci were further subjected to IMVIC tests, TSI, urease hydrolysis, catalase, oxidase and coagulase tests as well as other standard biochemical tests (Koneman et al., 2005 and Quinne et al., 2011) to identify the isolates.

2- Antibacterial bio-gram assay against the isolated Staphylococcus spp.:-

It was applied according to the National Committee for Clinical Laboratory Standards (NCCLS, 2008) using disk diffusion technique on Mueller Hinton agar. It was applied following 3 steps:-

a- Antibiotic susceptibility test:- Randomly selected singly isolated strains of S.aureus and CNS were subjected to 14 commercially available antibiotics discs [ciprofloxacin; CIP $(5 \mu \mathrm{g})$, norfloxacin; NOR $(5 \mu \mathrm{g})$, levofloxacin; LEV $(5 \mu \mathrm{g})$, Enrofloxacin; ENR $(5 \mu \mathrm{g})$, ofloxacin; OFX $(5 \mu \mathrm{g})$, amoxicillin-clavulanic acid; AMC (30 $\mu \mathrm{g})$, amoxicillin; AMX (25 $\mu \mathrm{g})$,

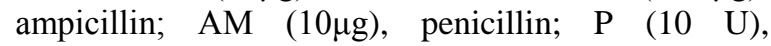
tetracycline; TE (30 $\mu \mathrm{g})$, florofenicol: $\mathrm{FFC}(30 \mu \mathrm{g})$, gentamycin; CN $(10 \mu \mathrm{g})$, streptomycin; S $(10 \mu \mathrm{g})$ and

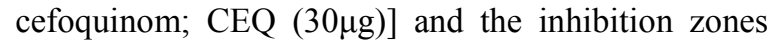
were recorded as sensitive, intermediate susceptibility and resistant according to the NCCLS recommendations.

b- Using natural alternative antimicrobial agents alone:- Lysozyme, lactoferrin, serum amyloid A and haptoglobin were used as natural antibacterial agents against the isolated Staphylococcus spp. using disk diffusion method by saturating clean discs with $100 \mu \mathrm{l}$ of $10 \mathrm{mg} / \mathrm{ml} \mathrm{Lz}$ once, $100 \mu \mathrm{l}$ of $10 \mathrm{mg} / \mathrm{ml} \mathrm{Lf}$ alone, $100 \mu 1$ of SAA alone and 100 $\mu$ l of Hp (Sunredbio Co., Shanghai, China).

c- Combination between commercial antibiotics and natural alternative antimicrobial agents:- The selected strains of S.aureus and CNS were subjected to the previously mentioned antibiotic discs saturated with $5 \mu 1 /$ disc of each of Lz, Lf, SAA and Hp with the same concentrations mentioned in step (b). The results were recorded by measuring the inhibition zones and scored as sensitive, intermediate susceptibility and resistant according to the NCCLS recommendation

\section{C-Immunological studies:}

1- Preparation of $S$. aureus strains for PAGE: Bacterial isolates grew in BHI broth, were collected by centrifugation at $10,000 \mathrm{~g}$ for 10 minutes, washed with physiological saline, diluted by physiological saline to $1.5 \mathrm{ml} / \mathrm{v}$. Cell suspension was sonicated for 3 minutes (at level 4), then centrifuged at 11,000 $\mathrm{g}$ for 3 minutes. Supernatant obtained was taken and stored at $0-4{ }^{\circ} \mathrm{C}$ for further analysis according to Tuasikal et al. (2012).
2- Analysis of protein profile of the tested udder tissue samples using SDS-PAGE: Protein was purified from camel's udder tissue samples according to Dignam (1990) and compared with standard bovine $\mathrm{Lz}$, Lf, SAA and $\mathrm{Hp}$ for determining the concentration of these immunological bioactive parameters in the udder tissues.

3- Polyacrylamide gel electrophoresis: Coomassie blue staining analysis of proteins was carried out by standard protocols (Laemmli, 1970). The selected tissue samples with mastitis where submitted to SDSPAGE and their protein patterns were compared with a database of normalized protein fingerprints derived from normal tissue samples.

4- Computer-aided analysis of the gels: Images of the gels were captured using a sharp JX-330 flat-bed scanner and image analysis of the protein profiles was performed using Amersham Pharmacia Biotech Image master 2-D Elite software.

\section{D- Histopathological examinations:}

1- Histopathological procedures: The udder was incised quickly and mammary tissue parenchyma were immediately fixed in $10 \%$ buffered formalin for routine histopathological examination. The fixed specimens were trimmed, washed, dehydrated in ascending grades of alcohol, cleared in xylene and embedded in paraffin. The embedded samples were sectioned at 3-5 $\mu \mathrm{m}$ thickness, stained with $\mathrm{H} \& \mathrm{E}$ stain according to Suvarna et al. (2013).

2- Histochemical procedures: Masson's Trichrome stain was used for connective tissue proliferation. All these procedures were applied as previously described by, Suvarna et al. (2013), in addition to cytoplasmic protrusions. For demonstration of AP activity and density of protein staining (mercurybromophenol blue) in mammary epithelial cells were determined according to El-Sayed et al. (2009) was applied then examined using a light microscope.

3- Histomorphometric analysis: It was applied on The paraffin-embedded mammary tissues that stained with H\& E for measurement of mammary alveolar diameter, number of alveoli and alveolar epithelial cell population as well as inter lobular connective tissue thickness in non-mastitic and mastitic she camel mammary gland using a light microscope (BX50, Olympus, Tokyo, Japan) equipped with a digital camera and software program (Image Pro6, Tokyo, Japan) that performed according to Hussain et al. (2012c). The following parameters were estimated among 5 different sections from mastitic she-camel from which isolated S.aureus as single infection and compared to non mastitic one. The average numbers of alveolus, alveolar cell population cells $(\mu 2)$ as well as alveolar diameter and the interlobular connective tissue thickness in $(\mu)$ were calculated for each case, 
in randomly detected five microscopic fields according to EL-Sayed et al. (2013); i.e. the total counted sections are twenty.

* Number of alveoli and the alveolar epithelial cell population in $(\mu 2)$ : The sections were viewed by the light microscope at 40x then the fields were examined at $400 x$ for manually counting of the alveolar number and the number of cells per alveolus using a computer.

* Alveolar diameter in $(\mu)$ : they were measured at $\mathrm{x} 100$. A straight line was drawn vertically from basement membrane to basement membrane at margins of the alveoli. The line runs from the outermost boundary across the lumen to the opposite end of the alveoli. These figures were automatically generated with the aid of the software.

* Interlobular connective tissue thickness in $(\mu)$ : A straight line was drawn at two opposite highest of the interlobular connective tissue. The measurement was done at $\mathrm{x} 100$.

E- Statistical analysis: The obtained results and morphometric data were subjected to analysis of variance according to Sendecor and Cochran (1982). Values were expressed as mean \pm SE. Statistical comparisons between the means of different experimental groups were made with completely randomized one-way ANOVA "Student_ Newman Keuls test "by COSTAT program version one. A probability " $\mathrm{P}$ " value of $<0.05$ was assumed for statistical significance.

\section{RESULTS}

Table (1) showed bacteriological examination of the collected 50 she camel's udder tissue samples and revealed that Staphylococcus spp. were the most common isolated bacteria $(90 \%)$ followed by Environmental Streptococcus spp. (40\%) then E.coli (26\%). Isolated Staphylococcus spp. were found either as single or mixed infection. S.aureus was found with a percentage of $(10 \%)$ as single infection and $(20 \%)$ as mixed infection while CNS were represented (24\%) and (36\%) as single and mixed infection, respectively. Environmental Streptococcus spp. and E.coli were found as mixed infection only with S.aureus and/or CNS with percentages of $40 \%$ and $24 \%$, respectively. The overall infected udder tissue samples were 45 out of $50(90 \%)$ while only $5 / 50$ (10) tissues samples showed no bacterial isolation on the used media.

Table 1: Bacteriological results of the examined mammary tissue samples.

\begin{tabular}{|c|c|c|c|c|c|c|c|c|c|c|}
\hline \multirow{3}{*}{$\begin{array}{l}\text { Bacterial } \\
\text { isolation }\end{array}$} & \multicolumn{4}{|c|}{ Staphylococcus spp. } & \multirow{2}{*}{\multicolumn{2}{|c|}{$\begin{array}{c}\text { Environmental } \\
\text { Streptococcus spp. }\end{array}$}} & \multirow{2}{*}{\multicolumn{2}{|c|}{ E.coli }} & \multirow{2}{*}{\multicolumn{2}{|c|}{$\begin{array}{l}\text { Bacteriologically negative } \\
\text { samples }\end{array}$}} \\
\hline & \multicolumn{2}{|c|}{ S.aureus } & \multicolumn{2}{|c|}{ CNS } & & & & & & \\
\hline & No. & $\%$ & No. & $\%$ & No. & $\%$ & No. & $\%$ & No. & $\%$ \\
\hline $\begin{array}{l}\text { Single } \\
\text { infection }\end{array}$ & 5 & 10 & 12 & 24 & - & - & - & - & 5 & 10 \\
\hline $\begin{array}{l}\text { Mixed } \\
\text { infection }\end{array}$ & 10 & 20 & 18 & 36 & 20 & 40 & 13 & 26 & & \\
\hline Total & 15 & 30 & 30 & 60 & 20 & 40 & 13 & 26 & 5 & 10 \\
\hline
\end{tabular}

$\%$ were calculated according to total number of examined sample $(n=50)$

As mastitis caused by S.aureus has been documented to be one of the most important udder infections in dairy animals. So, this study gave special attention to Staphylococcus spp. especially for the highly antibiotic resistant strains.

S.aureus and CNS strains that were isolated as single infection were selected, prepared after biochemical identification and used for studying the effect of antibiotics and their natural substitutes (Lz, Lf, SAA and $\mathrm{Hp}$ ) on the previous strains. Antimicrobial susceptibility of S.aureus and CNS were divided into 3 steps:-
First one, antibiotic discs were used alone on the selected S.aureus and CNS strains. This step showed high resistance to antibiotic discs as showed in fig. $3 \mathrm{~A}$ and fig. 4A, respectively.

In the second step, alternatives to antibiotic (Lz, Lf, SAA and Hp) were used alone. Table (2) and fig. (1, 2) explained that $\mathrm{Lz}, \mathrm{Lf}, \mathrm{SAA}$ and $\mathrm{Hp}$ were used alone as antibacterial substances. Lysozyme and Lf showed antibacterial effect on S.aureus as the inhibition zones were $18 \mathrm{~mm}$ and $13 \mathrm{~mm}$ respectively, while in CNS were $20 \mathrm{~mm}$ and $16 \mathrm{~mm}$ respectively, but Staphylococcus spp. either S.aureus or CNS showed high resistance to SAA and Hp when used alone as antibacterial substances. 
Table 2: Using of alternatives for antibiotics against S.aureus and CNS isolated strains.

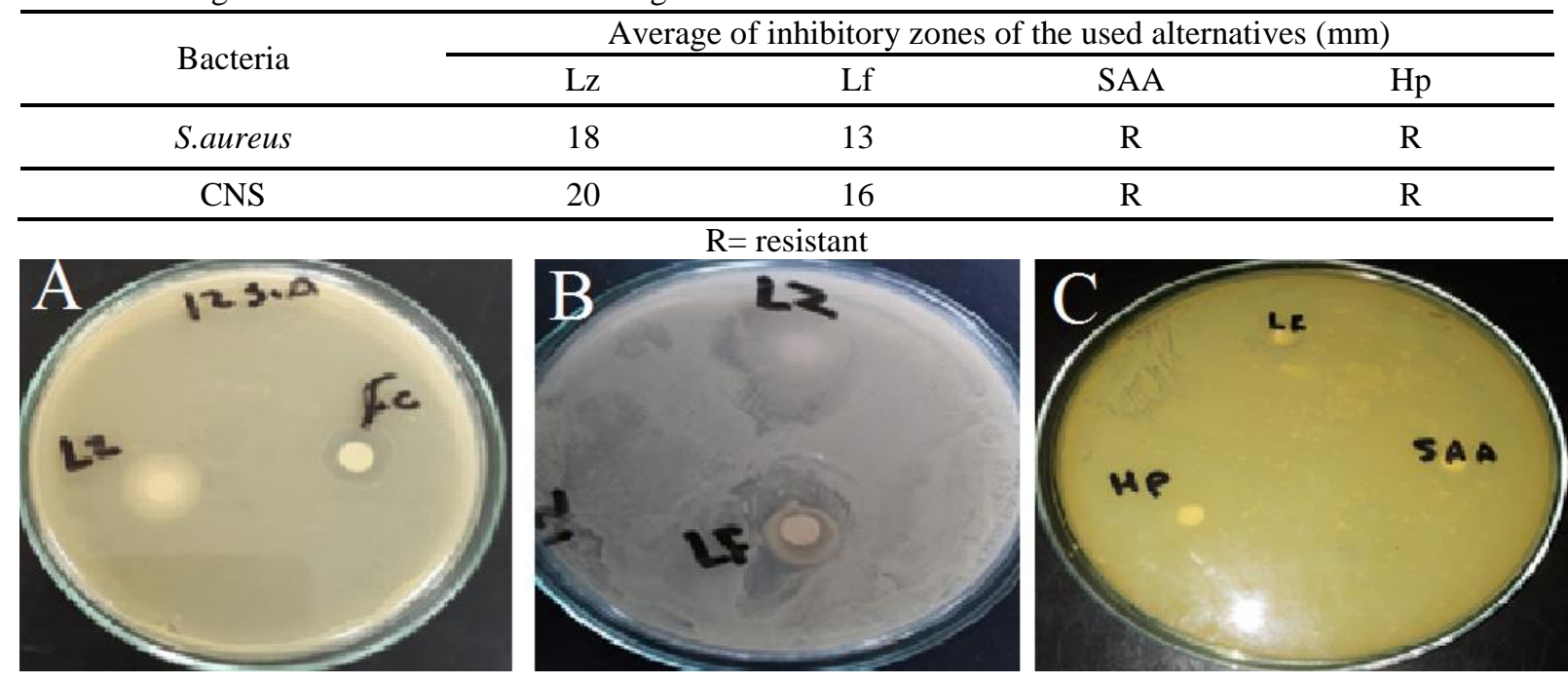

Fig. 1: Showed different antimicrobial effects of Lz, Lf, SAA and Hp alone on different strains of S.aureus.
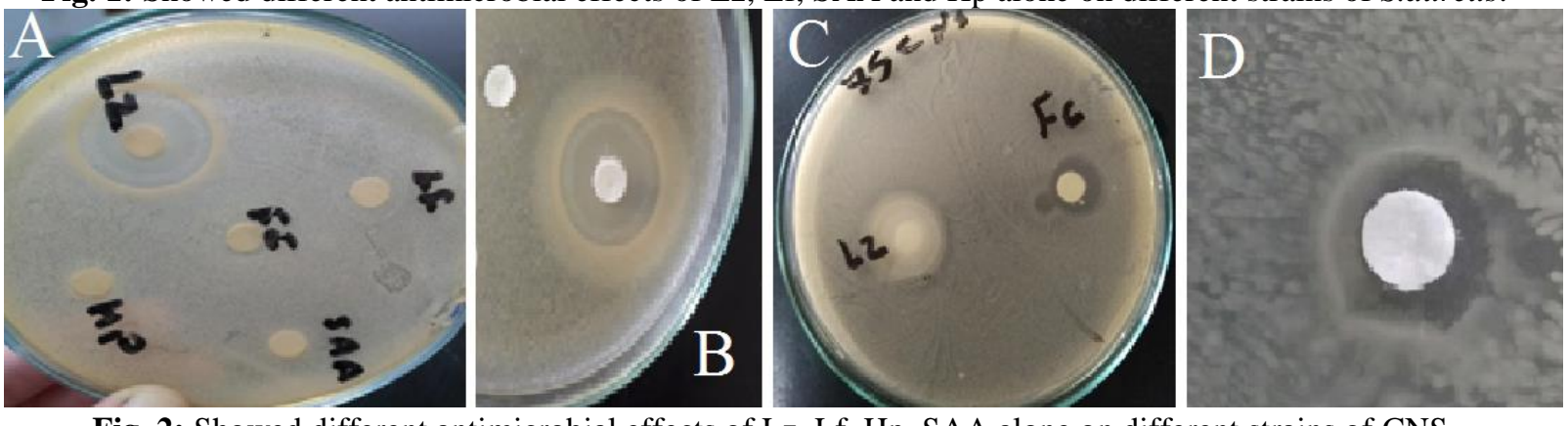

Fig. 2: Showed different antimicrobial effects of Lz, Lf, Hp, SAA alone on different strains of CNS.

In the third step, antibiotic discs were used in combination with the other alternatives to detect the synergistic effect between both of them for S.aureus and CNS. Table (3) and fig. (3) showed significant synergistic antibacterial effect of $\mathrm{Lz}$ then Lf followed by SAA and $\mathrm{Hp}$, respectively, with antibiotics against
S.aureus while S.aureus showed high resistance to antibiotics when used alone. Correlation coefficient showed as difference in the letters between antibiotic when used alone and when saturated with any of other alternatives.

Table 3: Detection of the synergistic effect of the combination between antibiotics and their alternatives on highly resistant isolated S.aureus strains.

\begin{tabular}{|c|c|c|c|c|c|}
\hline \multirow[b]{2}{*}{ Antibiotic } & \multicolumn{5}{|c|}{ Diameter of inhibition Zones $(\mathrm{mm})$ of antibiotics alone or combined with other alternatives. } \\
\hline & $\begin{array}{c}\text { Antibiotics } \\
\text { alone }\end{array}$ & Antibiotics $+\mathrm{Lz}$ & Antibiotics $+\mathrm{Lf}$ & Antibiotics +SAA & Antibiotics $+\mathrm{Hp}$ \\
\hline AMX & $6^{\mathrm{c}}$ & $12^{\mathrm{a}}$ & $10^{\mathrm{a}}$ & $8^{\mathrm{b}}$ & $8^{\mathrm{b}}$ \\
\hline AMC & $6^{\mathrm{b}}$ & $15^{\mathrm{a}}$ & $18^{\mathrm{a}}$ & $12^{\mathrm{a}}$ & $13^{\mathrm{a}}$ \\
\hline AM & $6^{\mathrm{a}}$ & $6^{\mathrm{a}}$ & $6^{\mathrm{a}}$ & $6^{\mathrm{a}}$ & $6^{\mathrm{a}}$ \\
\hline TE & $6^{c}$ & $15^{\mathrm{a}}$ & $13^{\mathrm{a}}$ & $8^{b}$ & $10^{\mathrm{b}}$ \\
\hline $\mathrm{P}$ & $13.33^{b}$ & $18.66^{\mathrm{a}}$ & $17^{\mathrm{a}}$ & $18^{\mathrm{a}}$ & $15^{\mathrm{b}}$ \\
\hline FFC & $20^{b}$ & $31.66^{\mathrm{a}}$ & $30.33^{\mathrm{a}}$ & $29^{\mathrm{a}}$ & $30^{\mathrm{a}}$ \\
\hline LEV & $12^{\mathrm{c}}$ & $18^{\mathrm{a}}$ & $16.66^{\mathrm{a}}$ & $14.33^{b}$ & $12^{\mathrm{c}}$ \\
\hline NOR & $6^{b}$ & $8^{a}$ & $6^{\mathrm{b}}$ & $6^{\mathrm{b}}$ & $6^{\mathrm{b}}$ \\
\hline CIP & $6^{\mathrm{c}}$ & $12^{\mathrm{a}}$ & $10^{b}$ & $8^{b}$ & $6^{\mathrm{c}}$ \\
\hline ENR & $12.33^{\mathrm{b}}$ & $17.66^{\mathrm{a}}$ & $16.33^{\mathrm{a}}$ & $15^{\mathrm{a}}$ & $14.33^{\mathrm{a}}$ \\
\hline OFX & $8^{c}$ & $15.66^{\mathrm{a}}$ & $15^{\mathrm{a}}$ & $12^{\mathrm{b}}$ & $12.33^{b}$ \\
\hline $\mathrm{CN}$ & $14.66^{\mathrm{c}}$ & $22.66^{\mathrm{a}}$ & $21.33^{\mathrm{a}}$ & $20^{\mathrm{a}}$ & $18^{b}$ \\
\hline CEQ & $6^{c}$ & $12^{\mathrm{a}}$ & $8^{b}$ & $6^{c}$ & $6^{\mathrm{c}}$ \\
\hline$S$ & $6^{\mathrm{c}}$ & $18^{\mathrm{a}}$ & $17^{\mathrm{a}}$ & $8^{b}$ & $10^{\mathrm{b}}$ \\
\hline
\end{tabular}

The difference in the letters between antibiotic only and with other alternatives were significance $(\mathrm{p}<0.05)$ 


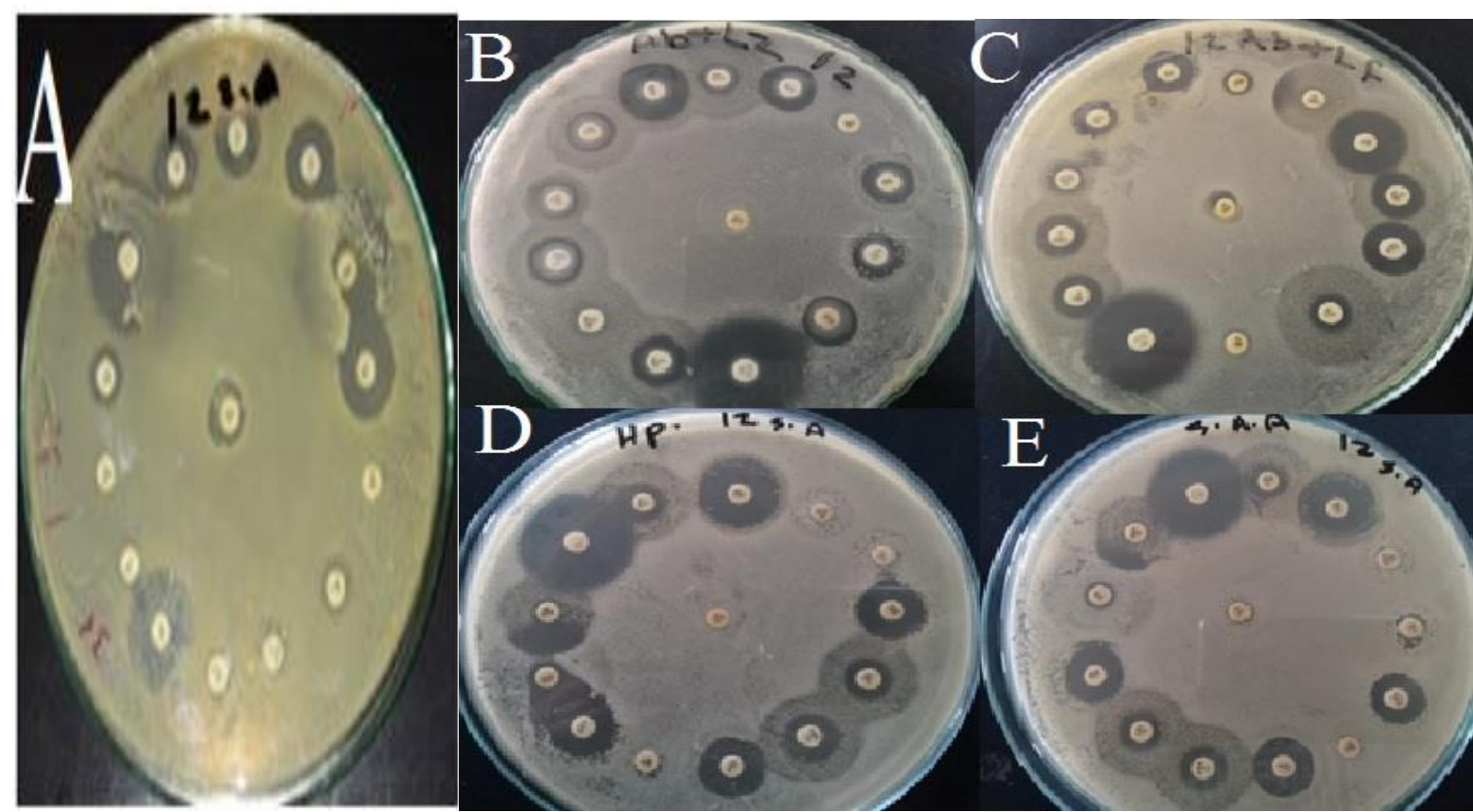

Fig. 3: Showed the antimicrobial effect of antibiotics alone (A) and saturated with $5 \mu$ l of each of Lz, Lf $(10 \mathrm{mg} / \mathrm{ml}), \mathrm{Hp}$ and SAA on S.aureus strain (B, C, D and E, respectively).

Table (4) and Fig. (4) showed significant synergistic antibacterial effect of the combination of $\mathrm{Lz}$ then $\mathrm{Lf}$ followed by SAA and $\mathrm{Hp}$ respectively, with antibiotics against CNS while CNS showed high resistance to antibiotics when they were used alone.
Correlation coefficient showed difference in the letters revealed synergistic effect between the combinations of antibiotics with the other alternatives than that of antibiotic only.

Table 4: Detection of the synergistic effect of the combination between antibiotics and their alternatives on isolated CNS strains.

Diameter of inhibition zones $(\mathrm{mm})$ of antibiotics alone or combined with other alternatives.

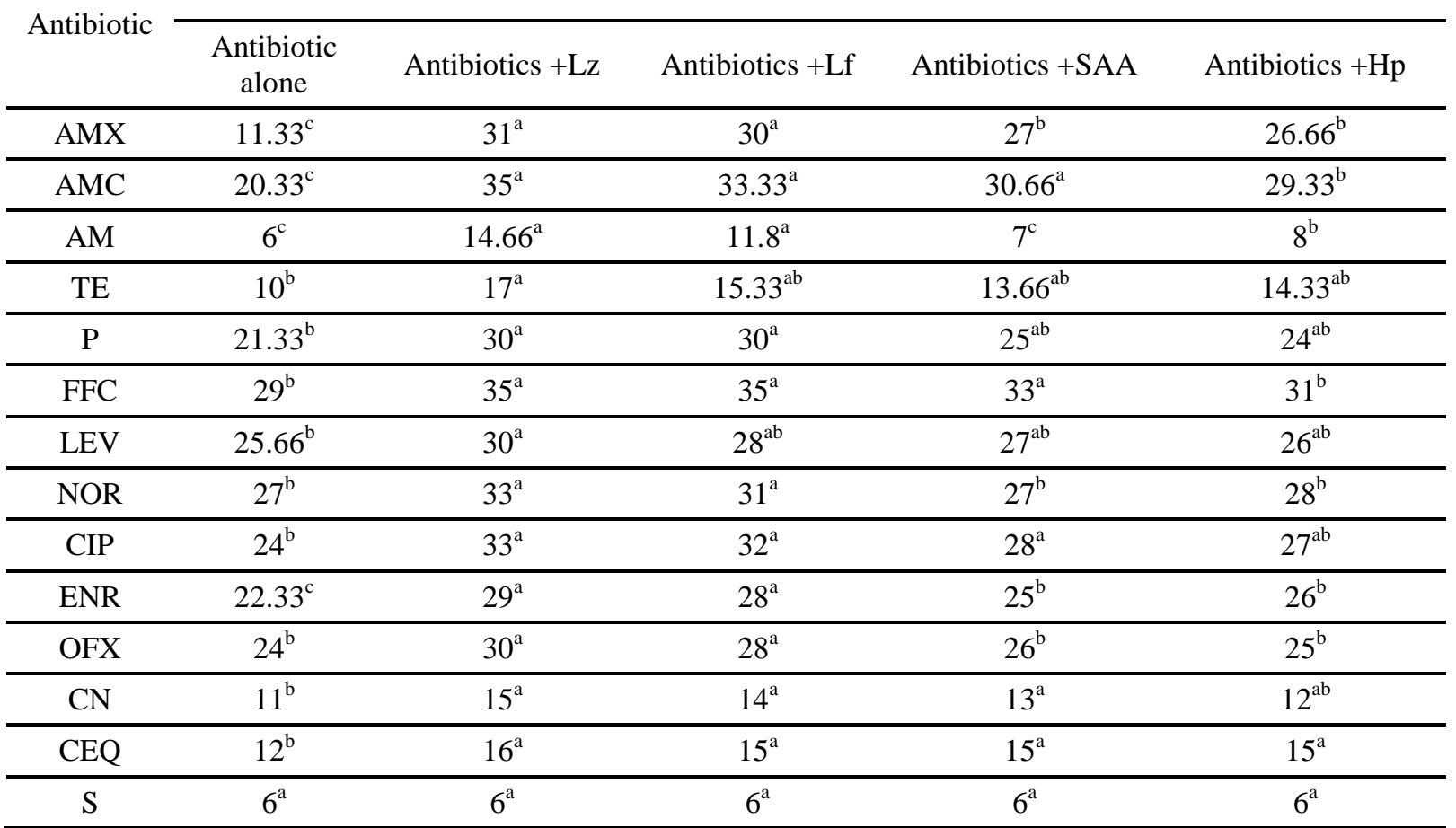

The difference in the letters between antibiotic only and with other alternatives were significance $(\mathrm{p}<0.05)$ 


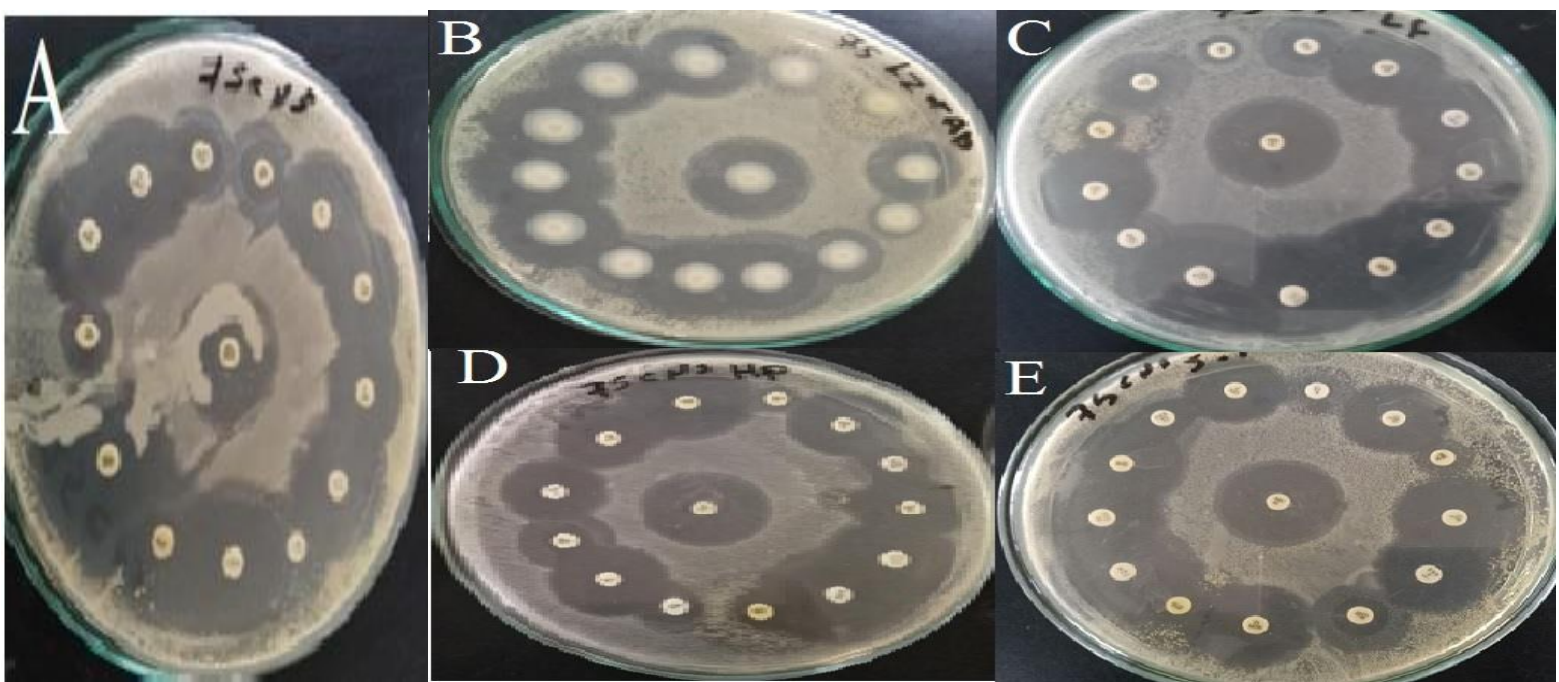

Fig. 4: Showed the antimicrobial effect of antibiotics alone (A) and saturated with Lz, Lf, Hp and SAA on CNS strain (B, C, D and E, respectively).

Different immunological bioactive parameters included Lz, Lf, Hp and mSAA (mammary SAA) were determined to evaluate the immunological status of the naturally infected she camel mammary tissue samples with S.aureus or CNS in comparison to bacteriologically negative mammary tissue samples. Table (5) and Fig. (5) showed that the concentrations of the Lz, Hp and SAA were significantly higher in tissue samples infected with both S.aureus and CNS when compared with non-infected tissue samples. While the concentration of Lf showed a significant rise in tissue samples infected with CNS when compared with tissue samples infected with $S$. aureus.

Table 5: Correlation between some immunological parameters in the mammary gland tissue and the isolated bacteria.

\begin{tabular}{ccccc}
\hline \multirow{2}{*}{ Isolated bacteria } & \multicolumn{4}{c}{ Average concentration of different immunological bioactive parameters } \\
\cline { 2 - 4 } & $\mathrm{Lz}$ & $\mathrm{Lf}$ & $\mathrm{SAA}$ & $\mathrm{Hp}$ \\
\hline S. aureus & $20.32 \pm 1.2^{* * *}$ & $12.33 \pm 1.4^{* *}$ & $19.83 \pm 1.4^{* * *}$ & $18.66 \pm 2.67^{* * *}$ \\
\hline CNS & $19.39 \pm 2.3^{* * *}$ & $19.7 \pm 1.1^{* * *}$ & $13.78 \pm 1.55^{* *}$ & $14.45 \pm 2.2^{* *}$ \\
\hline $\begin{array}{c}\text { Bacteriologically negative } \\
\text { tissue samples }\end{array}$ & $8.92 \pm 1.9$ & $8.67 \pm 1.3$ & $9.77 \pm 2.3$ & $9.35 \pm 1.98$ \\
\hline
\end{tabular}
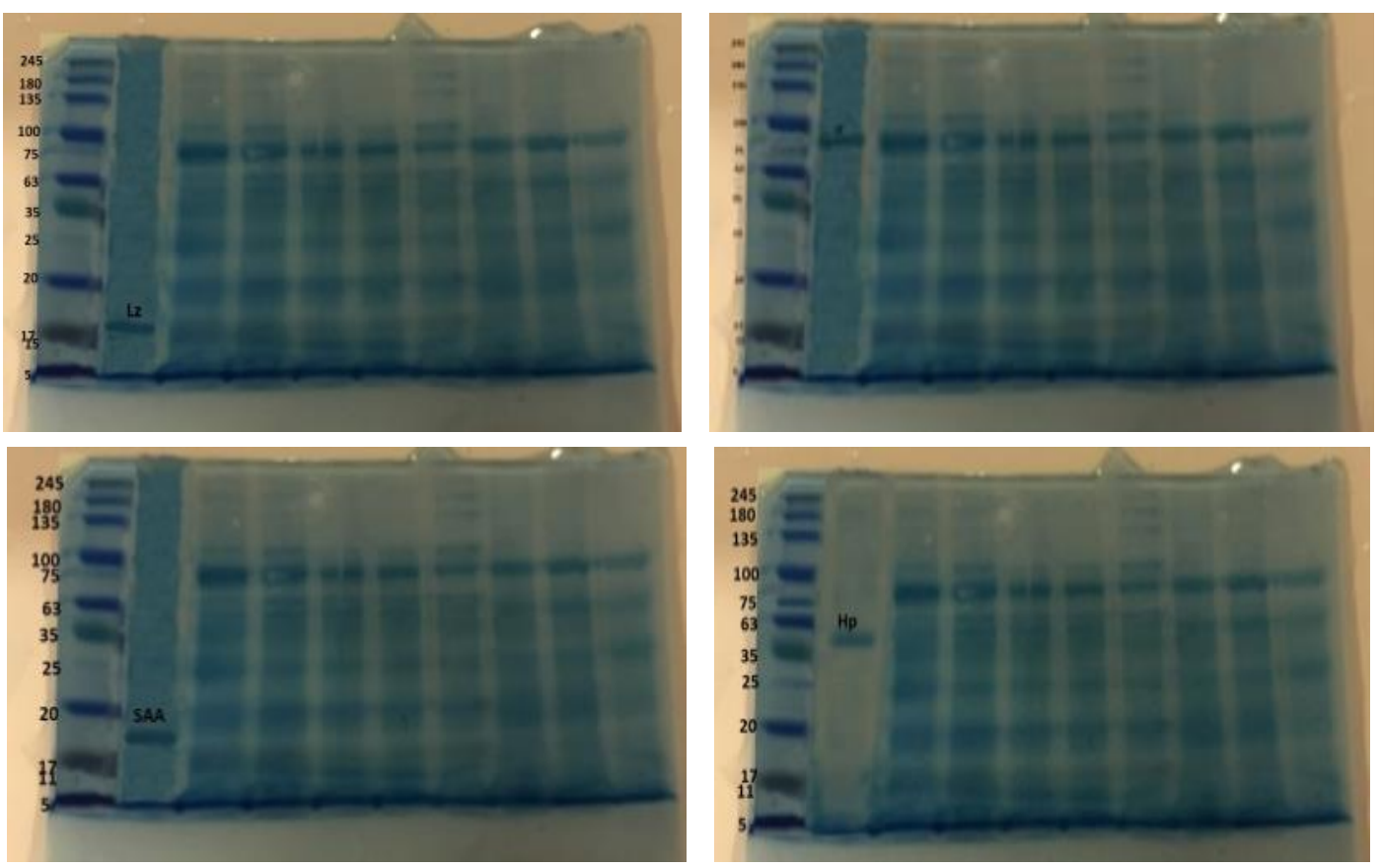

Fig. 5: Showed Lysozyme mol.wt. (14.33 KD), Lf mol.wt. (81.14KD), mSAA mol.wt. (17.02 KD) and Hp mol.wt. (35.02KD). 
We used the UPGMA clustering dendrogram analysis to compare the protein fingerprints of the isolated bacteria (Fig. 6\&7). The present dendrogram illustrated that there were no or weak similarities in the protein fingerprints of the different isolated $S$. aureus and CNS strains ranging from 0 to 0.36 , i.e approximately from 0 to $36 \%$ when converted to percent values as shown in table (6).

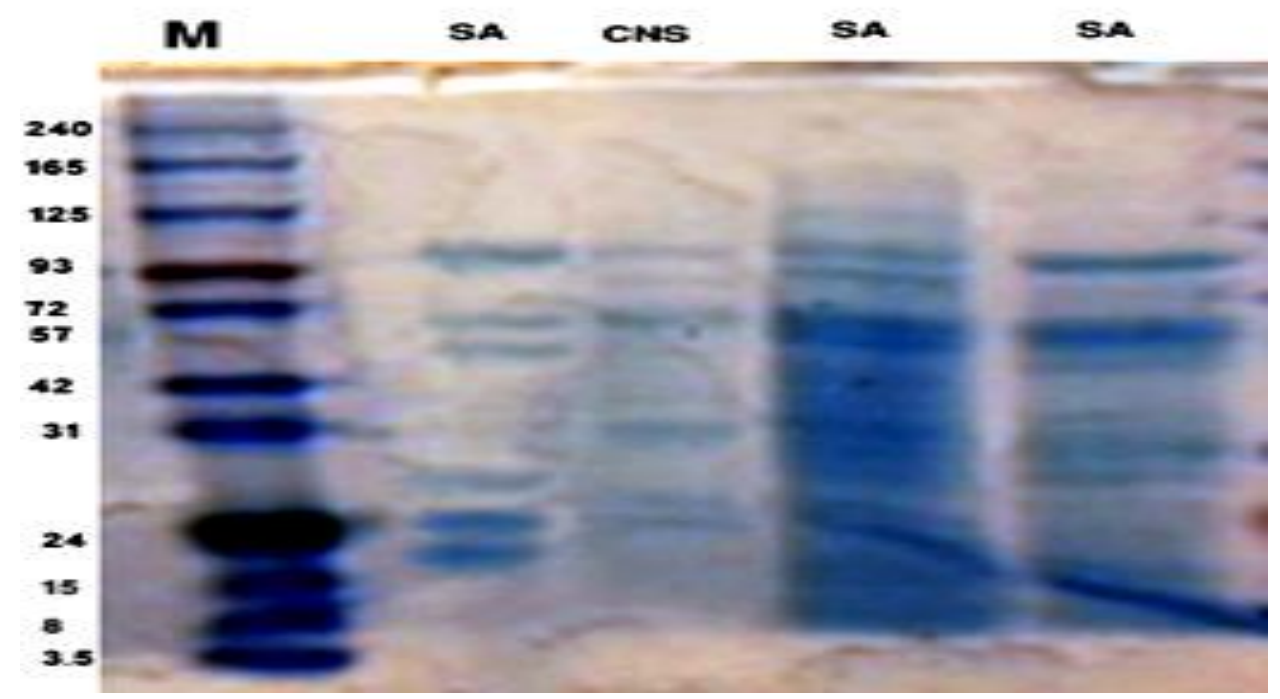

Fig. 6: Electrophoretic whole cell protein profiles of different isolated bacteria Lane 1: Molecular size marker; Lane 2: S.aureus., Lane 3: CNS, Lane 4:S.aureus, Lane 5: S.aureus.
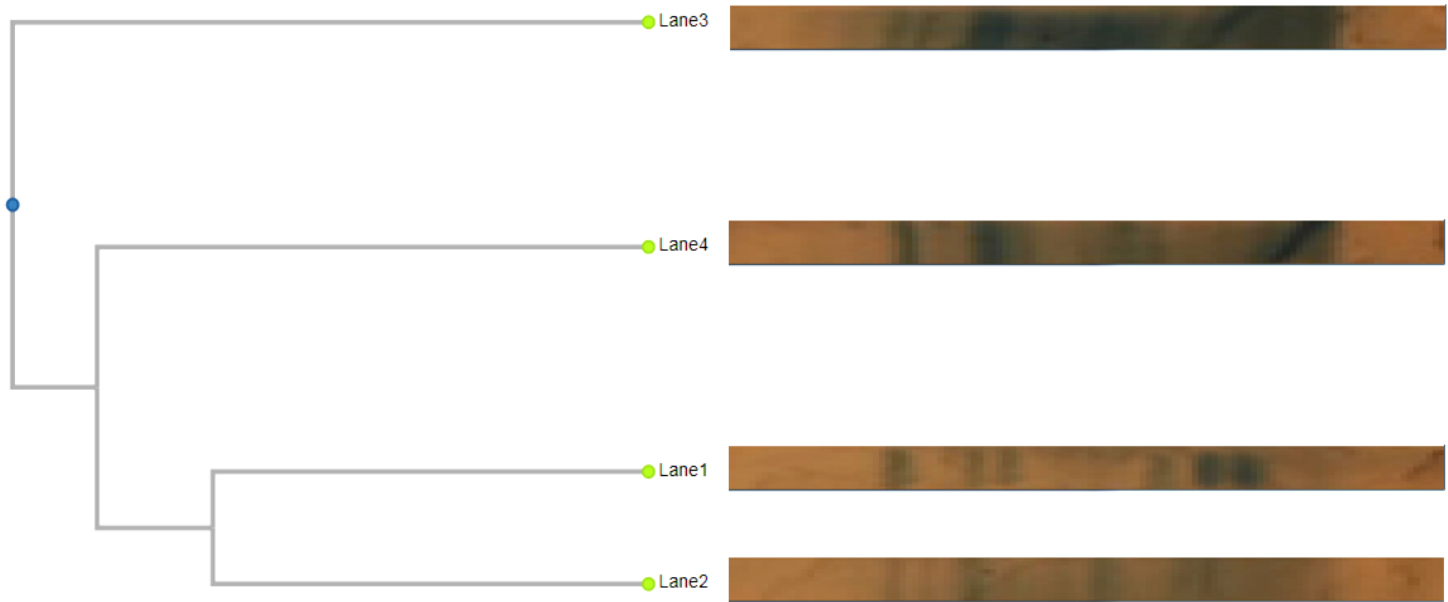

Fig. 7: Dendrogram analysis of the bacterial isolates protein bands, Lane1: S.aureus, Lane 2: CNS, Lane 3: S.aureus, Lane 4: CNS.

Table 6: The similarities between the protein fingerprints of different isolated S.aureus and CNS strains.

\begin{tabular}{ccccc}
\hline Isolated strains & S.aureus & CNS & S.aureus & CNS \\
\hline S.aureus & 1 & 0.36 & 0 & 0.18 \\
\hline CNS & 0.36 & 1 & 0.2 & 0.2 \\
\hline S.aureus & 0 & 0.2 & 1 & 0 \\
\hline CNS & 0.18 & 0.2 & 0 & 1 \\
\hline
\end{tabular}


Table 7: Types of mastitis of examined she camel mammary tissues depending on histopathological examination in relation to the isolated bacteria.

\begin{tabular}{|c|c|c|c|}
\hline Type of mastiis & Isolated bacteria & No. & $\%$ \\
\hline 1-Acute diffuse mastitis & $\begin{array}{l}\text { S.aureus (1), CNS (1), S.aureus }+ \text { Streptococcus spp. (2), } \\
\text { CNS +Streptococcus spp. (2), S.aureus }+ \text { CNS (1) }\end{array}$ & 7 & 14 \\
\hline $\begin{array}{l}\text { 2-Subacute interstitial } \\
\text { mastitis }\end{array}$ & $\begin{array}{l}\text { S.aureus (1), CNS (5), S.aureus+ Streptococcus spp. (3), } \\
\text { S.aureus+ E.coli+ CNS (2), S.aureus+ Streptococcus spp. + } \\
\text { CNS (1). }\end{array}$ & 12 & 24 \\
\hline $\begin{array}{l}\text { 3- Chronic interstitial } \\
\text { mastitis }\end{array}$ & 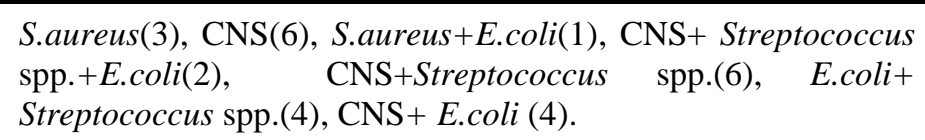 & 26 & 52 \\
\hline Total & & 45 & 90 \\
\hline
\end{tabular}

*Incidence was calculated according to the total no. of 50 mammary tissues of the examined she camels.

In the present work, all the positively cultured collected tissue sections were evaluated for histopathological alterations. Singly isolated S.aureus tissue sections revealed grossly, varied degrees of congestion and edema in some cases whereas fibrosis and paleness were noticed in the other most cases. Histopathologically, acute diffuse mastitis was detected in $14 \%$ of the cases and the isolated organisms were S.aureus (1), CNS (1), S.aureus + Streptococcus spp. (2), CNS + Streptococcus spp. (2), S.aureus+ CNS (1), only 2 of them showed suppuration. In addition 12 cases (24\%) showed subacute interstitial mastitis and the isolates were S.aureus (1), CNS (5), S.aureus+ Streptococcus spp. (3), S.aureust E.colit CNS (2), S.aureus+ Streptococcus spp.+ CNS (1). The majority of tissue samples $26(52 \%)$ showed fibrosis and paleness and the isolates were S. aureus (3), CNS (6), S.aureus+ E.coli (1), CNS+ Streptococcus spp.+ E.coli (2), CNS+ Streptococcus spp. (6), E.coli+ Streptococcus spp. (4), CNS+ E.coli (4).

Microscopically, seven (14\%) of tissue samples showed acute diffuse mastitis which characterized by sever vacuolar degeneration, desquamation and coagulative necrosis of the alveolar epithelium within the lumen forming eosinophilic exudates as well as, suppurative inflammatory response marked by neutrophil and macrophages infiltration with congestion (Fig.8). The interstitial tissues appeared oedematous and infiltrated with inflammatory cells mainly neutrophils and macrophages (Fig. 9). Wherever, the non-suppurative types owned few neutrophil infiltrations with lymphocytes and macrophage in the parenchyma without noticed coagulative necrosis and S.aureus colonies in side alveolar lumen of damaged alveoli (Fig.10). Whereas 11 tissue samples (24\%) of subacute interstitial mastitis showed mild vacuolization, desquamation of the alveolar epithelium with inflammatory cells infiltrations and vascular congestion. The interstitial tissues showed few neutrophils and mononuclear cellular infiltrations as well as mild oedema and vascular congestion (Fig.11). On the other side 26 $(52 \%)$ of tissue samples revealed chronic non suppurative interstitial mastitis that characterized by variable inflammatory changes ranging from the disappearance of the alveolar lumen, through fibrosis to the complete destruction of the parenchyma and interstitial, perialveolar, intra and inter alveolar fibrosis (Fig.12). The mammary lobules were atrophied or replaced completely by fibrous tissue accompanied with mononuclear cells infiltration mainly lymphocytes, macrophages and histiocytes (Fig.13). Prominent corpora amylacea were observed. Hyperplasia of epithelial lining of lactiferous ducts was noticed and associated with sub-epithelial mononuclear cell aggregations as well as lymphocytic exocytosis. Moreover, most of ducts were dilated with wall fibrous thickening and desquamation of the lining epithelium. Hypertrophy of some blood vessels wall with round cellular infiltration was seen (Fig.14). Increase of the interstitial, perialveolar, intra and inter acinar fibrosis were confirmed with Masson's Trichrome stain as greenish blue fibres (Fig. 15, 16, 17).

The activity of alkaline phosphatase in tissue sections of non mastitic animals were high secretory activity on the outer boundary of alveolar secretary cells. However, tissue sections taken from singly isolated S.aureus showed weak AP activity, on the outer membrane (Fig.18\&19).

Also, the thick-walled mammary alveoli with larger cells in normal non mastitic mammary tissues showed the greatest density of protein when evaluated by mercury-bromophenol blue stain while weak protein density detected in singly isolated S.aureus tissue sections comparing to the non-mastitis (Fig.20\&21). 
Table 8: Morphometric analysis of twenty counted sections from slaughtered she camel mammary parenchyma in non mastitic and mastitic samples (acute, subacute and chronic) caused by S.aureus as single infection.

\begin{tabular}{|c|c|c|c|c|}
\hline \multirow[b]{2}{*}{ Parameter } & \multicolumn{4}{|c|}{ Types of mastitis } \\
\hline & $\begin{array}{l}\text { Non mastitic } \\
\text { tissue }\end{array}$ & $\begin{array}{l}\text { Acute diffuse } \\
\text { mastitic tissue }\end{array}$ & $\begin{array}{c}\text { Subacute interstitial } \\
\text { mastitic tissue }\end{array}$ & $\begin{array}{c}\text { Chronic interstitial } \\
\text { mastitic tissue }\end{array}$ \\
\hline $\begin{array}{l}\text { Number of alveoli } \\
(\mu 2)\end{array}$ & $9.576 \pm 0.7113^{\mathrm{a}}$ & $6.912 \pm 0.6707^{b}$ & $8.074 \pm 0.5463^{\mathrm{ab}}$ & $6.240 \pm 0.8159^{b}$ \\
\hline $\begin{array}{l}\text { Alveolar diameter } \\
(\mu)\end{array}$ & $7.922 \pm 1.518^{\mathrm{a}}$ & $5.011 \pm 1.474^{\mathrm{b}}$ & $3.636 \pm 1.801^{\mathrm{c}}$ & $0.627 \pm 0.0733^{\mathrm{d}}$ \\
\hline $\begin{array}{l}\text { Alveolar cell } \\
\text { population }(\mu 2)\end{array}$ & $74.60 \pm 4.474^{\mathrm{a}}$ & $49.59 \pm 4.106^{\mathrm{b}}$ & $18.18 \pm 2.020^{\mathrm{c}}$ & $13.57 \pm 0.9911^{\mathrm{d}}$ \\
\hline $\begin{array}{l}\text { Interstitial connective } \\
\text { tissue }(\mu)\end{array}$ & $160.7 \pm 24.77^{\mathrm{a}}$ & $178.5 \pm 20.91^{\mathrm{b}}$ & $261.7 \pm 22.29^{c}$ & $293.8 \pm 7.091^{\mathrm{d}}$ \\
\hline
\end{tabular}

Means within the same row are bearing different letter superscripts (a, b, c \& d) differ significantly $(\mathrm{P} \leq 0.05)$.
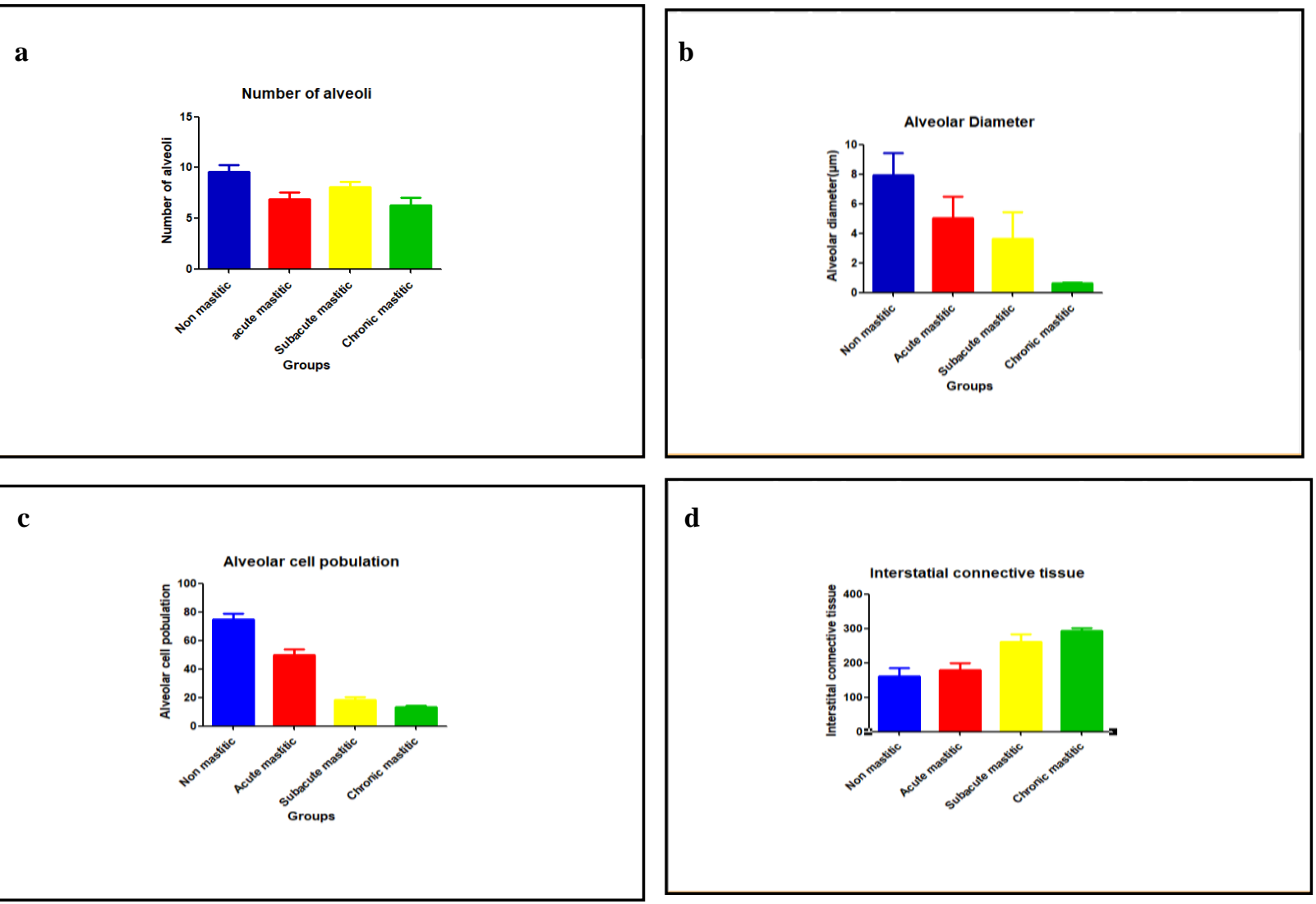

Fig. charts (I; a, b, c and d): Showed morphometric analysis of alveolar number, diameter and cell population as well as interstitial connective tissue of different types of mastitis caused by S.aureus infection.

Regarding to the morphometric evaluation in the present study, as showed in Fig. charts (I; a, b, c and d) mammary parenchyma of she camel from 5 different tissue sections from which recovered S.aureus as single infection, it was noticed that there were significant decreases $(\mathrm{P} \leq 0.05)$ in alveolar number, diameter and cell population per field, while the interstitial connective tissue showed significant increases $(\mathrm{P} \leq 0.05)$ in each of acute diffuse mastitis, subacute interstitial mastitis and chronic interstitial mastitis when compared to the non mastitic once. 

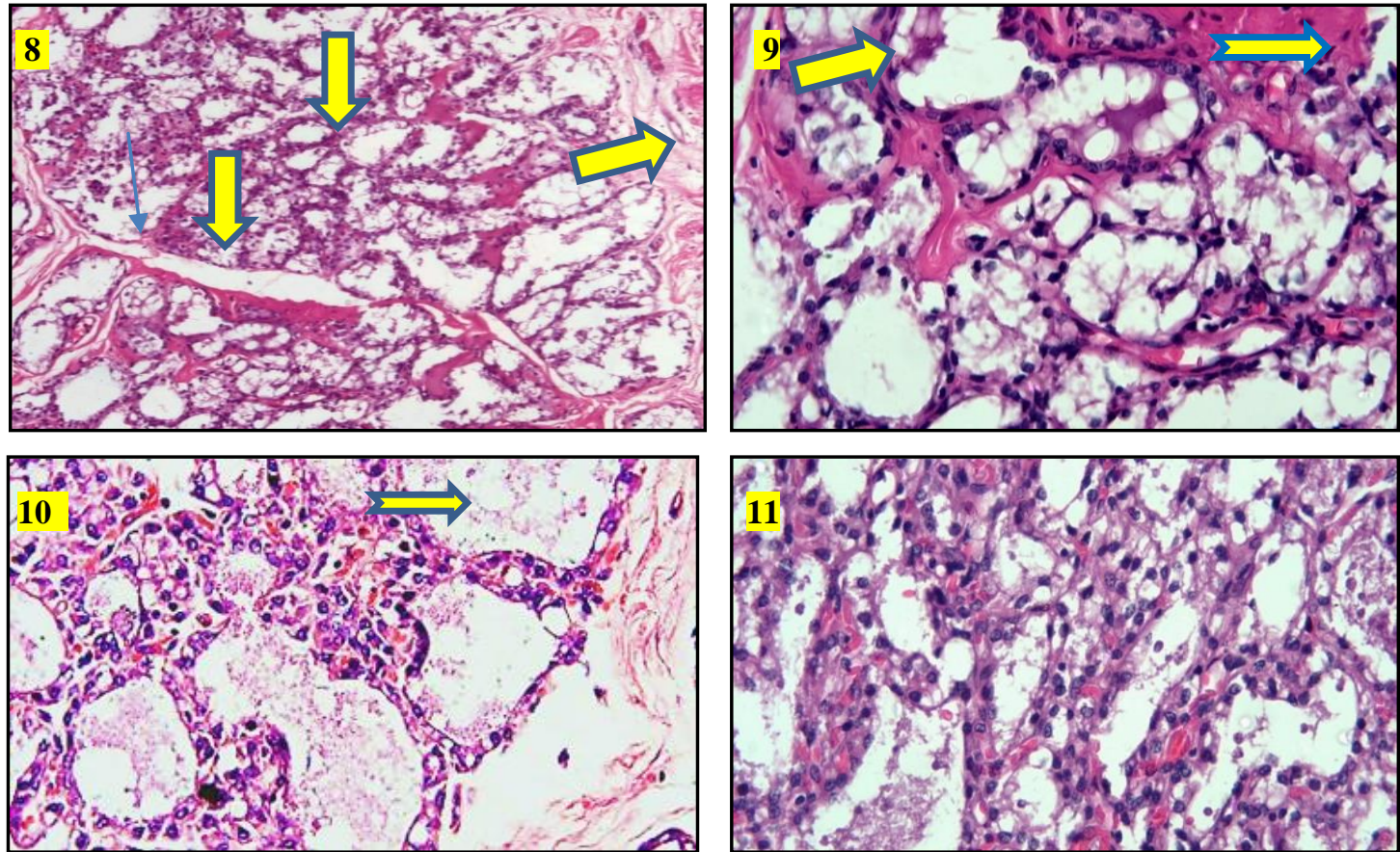

Fig. 8: She camel singly infected S.aureus mammary gland showing acute suppurative mastitis, characterized by atrophy and damaged alveoli as well as marked suppuration (yellow arrow) and vascular congestion (H\&E, X100).

Fig. 9: She camel singly infected S.aureus mammary gland showing acute suppurative mastitis with marked suppuration (yellow arrow) of damaged alveoli with neutrophils and macrophages infiltration as well as necrosis and desquamated of alveolar epithelium (H\&E, X400).

Fig. 10: She camel singly infected S.aureus mammary gland showing acute non suppurative mastitis with S.aureus colonies (yellow arrow) in side the alveolar lumen of damaged alveoli (H\&E, X400).

Fig. 11: She camel singly infected S.aureus mammary gland showing subacute mastitis vascular congestion and mononuclear cell infiltrations H\&E, X40).
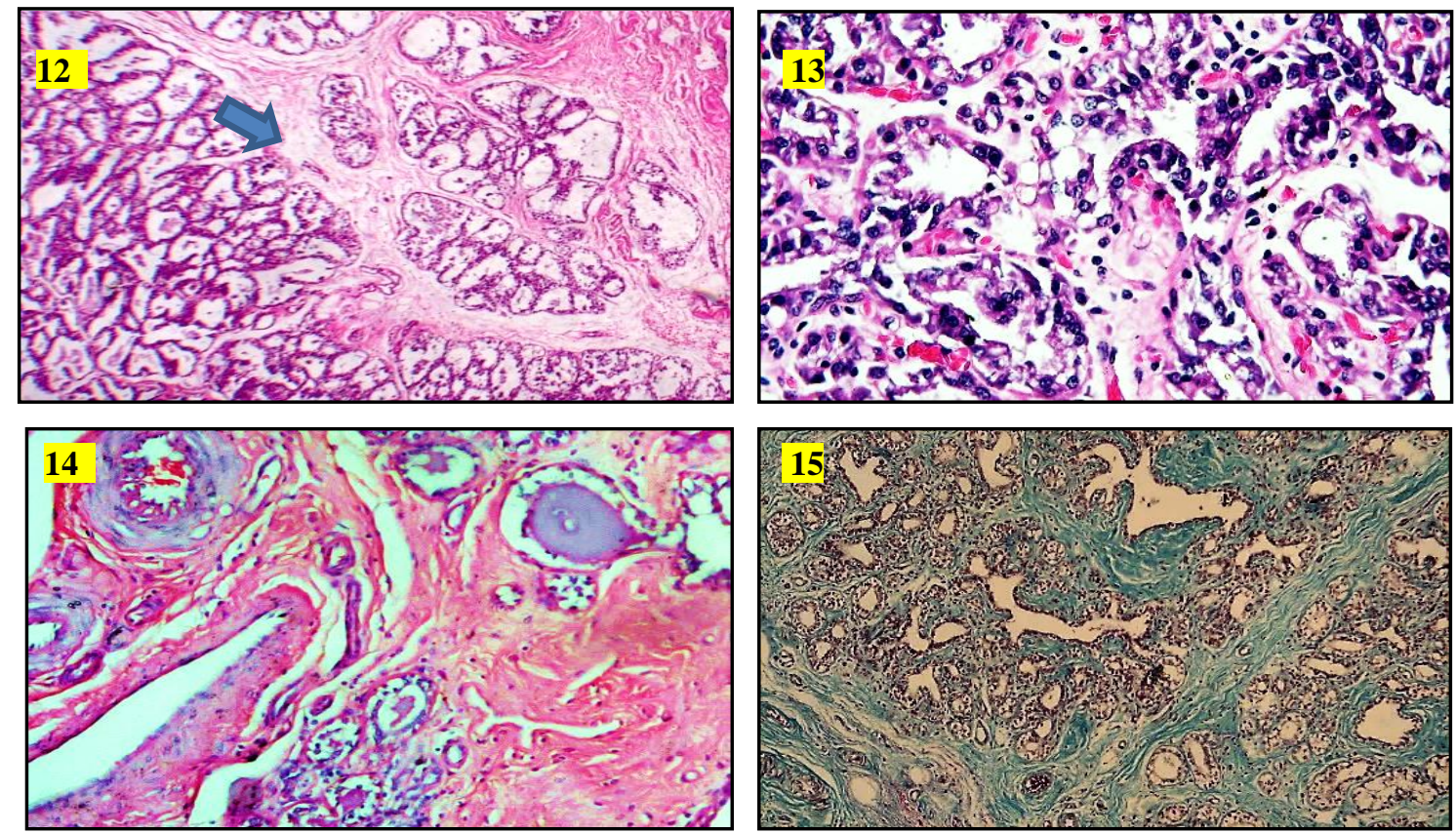

Fig. 12: She camel mammary gland showing chronic interstitial non suppurative mastitis with atrophied lobules (blue arrow), diffuse interstitial fibrous connective proliferation and mononuclear cell infiltrations H\&E, X40).

Fig. 13: She camel singly infected S.aureus mammary gland showing high power of the previous one (H\&E, X100).

Fig. 14: She camel singly infected S.aureus mammary gland showing chronic interstitial non suppurative mastitis with fibrous connective proliferation, atrophied lobules(green arrow), hypertrophied vascular wall (blue arrow) and hypertrophied ducal epithelium as well as corpora amylasia (black arrow) ( H\&E, X100).

Fig. 15: She camel singly infected S.aureus mammary gland showing chronic interstitial non suppurative mastitis, fibrous connective proliferation (Masson's Trichrome stain, X40). 

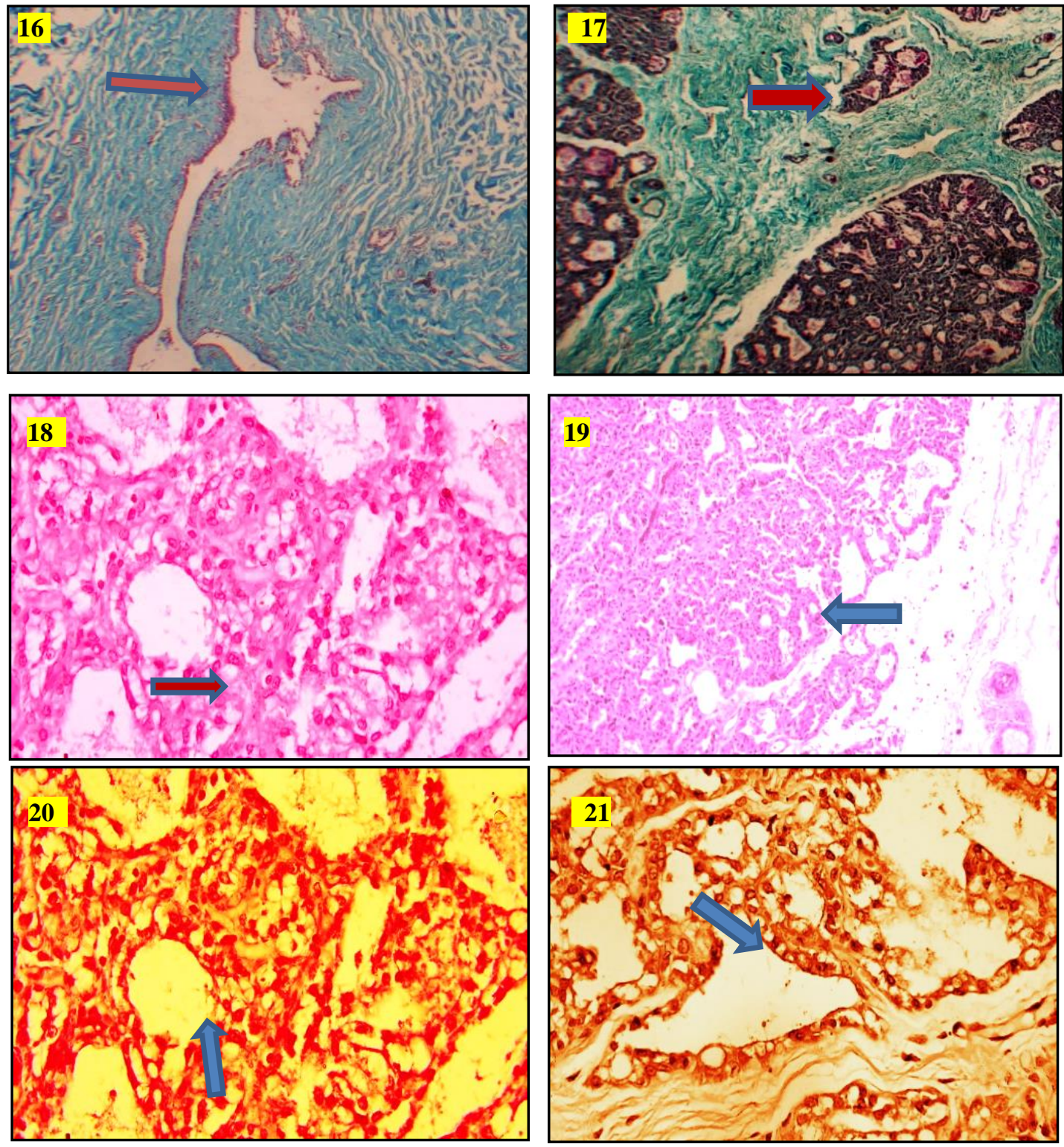

Fig. 16: She camel singly infected S.aureus mammary gland showing chronic interstitial non suppurative mastitis, fibrous connective proliferation and ducal epithelium (red arrow) (Masson's Trichrome stain, X100).

Fig. 17: She camel singly infected S.aureus mammary gland showing chronic interstitial non suppurative mastitis, fibrous connective proliferation with atrophied lobules (red arrow) (Masson's Trichrome stain, X40)

Fig. 18: Section of mammary tissue from non mastitic she camel showing high level of alkaline phosphatase activity (blue arrow) (alkaline phosphatase X100).

Fig. 19: Section of mammary tissue from singly infected S.aureus mastitic she camel showing no to weak alkaline phosphatase activity (blue arrow) (alkaline phosphatase X100).

Fig. 20: Section of mammary tissue from non mastitic she camel showing high protein staining (blue arrow) (mercury-bromophenol blue X100).

Fig. 21: Section of mammary tissue from singly infected S.aureus mastitic she camel showing activity of showing weak protein staining (blue arrow) (mercury-bromophenol blue solution X100).

\section{DISCUSSION}

Mammary gland infections especially in she-camel lead to produce infected milk which is unacceptable as camel's milk have many therapeutics uses especially in Egypt, so in this study we tried to find alternative treatment to mammary gland pathogens with special references to Staphylococcus spp. because it is difficult to be treated as it can be embedded deeply in mammary gland tissues (Foster et al., 2014). In recent years, antibiotics resistance and its impact on human health have drawn much attention worldwide. Antibiotics residues in milk pose health hazards to consumers and of high economic importance because such milk unfit for processing and subsequent consumption (Salama et al., 2013). Moreover, the antibiotic therapy has many complications, such as hypersensitivity, direct 
toxicity, antibiotic-induced immunosuppression and super-infections. This is highlighting the need for new strategies for non-antibiotic therapy through the use of alternative novel antibacterial substances as Lz, Lf, SAA and Hp those used in this study.

In the present study, bacteriological examinations of she camel mammary gland tissues revealed that pathogens mainly caused mammary tissue inflammation were Staphylococcus spp. (90\%) in the form of single and or mixed infection with environmental Streptococcus spp. and E.coli. A lower percentage $(42.6 \%)$ of mixed infection of S.aureus and S.agalactiae of female camel mammary gland tissues was detected by Hegazy et al. (2004). Another study done in UAE at 2013 showed that the main pathogens causing mastitis were Staphylococcus (41.67\%) and Streptococcus spp. (21.67\%), Enterobacter spp. (15\%) and other bacteria with lower percents were isolated (Al-Juboori et al., 2013). Meanwhile another study was done in Sudan at 2013 showed that pathogens isolated were mainly Staphylococcus spp. (80.30\%) (Alamin et al., 2013). Woubit et al. (2001) reported that the major mastitis pathogens isolated included species of Staphylococcus, Streptococcus, Micrococcus, Corynebacterium and Bacillus and A.pyogenes, E.coli and P.haemolytica.

Bacteriological results revealed high percentage of Staphylococcus spp.; this high frequency of S.aureus in mammary gland infections could be due to ability of S.aureus to stay and survive in keratin layers of teat canal of animals (Qayyum et al., 2016 and Aqib et al., 2017).

In this study an in-vitro trail was performed to use naturally bioactive immunological agents suggested to have antibacterial activities as safe alternatives to traditionally used antibiotic for treatment of mastitis. Lysozyme and Lf when used alone it was noticed that, they had antibacterial activity on S.aureus and CNS that came in agreement with Amany et al. (2005); Conesa et al. (2008); Mona et al. (2010); Gizachew et al. (2014) and Abrhaleya and Leta (2018) they reported that $\mathrm{Lz}$ and $\mathrm{Lf}$ exerted antibacterial, antiviral, antifungal and anti-parasitic activity.

Rabab (2009) studied the antimicrobial action of Lf against different microorganisms. She recorded that Lf had a pronounced effect on the growth of on some pathogenic bacteria as S.aureus, S.pyogenes, E.coli, and E.aerogenes and none of them was able to resist the bacteriostatic effect of Lf that came in accordance with our study which showed growth inhibition of Staphylococcus spp. either S.aureus or CNS when used Lf alone with relatively higher inhibitory zone in case of CNS (16 versus $13 \mathrm{~mm}$ ). Recently Niaz et al. (2017) reported that isolated Lf from camel milk exhibited promising antibacterial activity against E.coli and S.aureus and the concentration of Lf 4 $\mathrm{mg} / \mathrm{ml}$ showed the best results against both the pathogens.

Al-Majali et al. (2007) studied the antibacterial effects of camel Lf against some selected isolated bacteria from subclinical mastitic milk and found that, all tested bacterial isolates were resistant to the camel Lf except S.aureus (20 isolates), S.agalactia (2 isolates), and 12 isolates Streptococci other than S.agalactiae. Abrhaleya and Leta (2018) stated that lactoferrin had potent antimicrobial and antiinflammatory properties, including bacterial inhibition for S.aureus and E.coli. Also Rabab (2009) said that the maximum growth inhibition of Lf was recorded with E.coli than any other strain and explained that may due to Lf is a glycoprotein which is able to bind two metal binding cations, preferably ferric ions at specific binding sites. Therefore, it competes with other bacteria for iron present in the media. Since E.coli is the highest strain for iron requirement in the growth, therefore it was the most affected by Lf. Previously, Kappeler et al. (1999) reported the inhibition effect of Lf against mastitic isolates of S.aureus but there was no effect against S.agalactiae and S.uberis. Meanwhile it was found that antimicrobial activity of Lf may be different in Gram-negative and Gram-positive bacteria due to the differences in the cell membrane structure. At the same time bacterial isolates (either Gram-positive or Gram-negative) were inhibited by in-vitro addition of Lf which can act either as a bacteriostatic and/or bactericidal agent. This difference in the activity may explain the wide range of Lf action. The presence of Lf binding proteins or Lf receptors on the surface of the microorganisms may partially explain the resistance of these isolates to Lf (Farnaud et al., 2004).

Lysozyme is among the minor milk proteins that attracted attention recently due to its potent antimicrobial activity against a wide range of microorganisms. Lysozyme has been shown to have antimicrobial activities towards bacteria, fungi, protozoan and viruses (Benkerroum, 2008 and Shakir et al., 2013). The current results revealed that Lz had strong antibacterial effect on S.aureus and CNS that was cleared with the large inhibitory zones (18 versus $20 \mathrm{~mm}$, respectively) when it was used alone. The antibacterial activity of lysozyme is essentially directed towards gram-positive bacteria, as their target cell-wall component (peptidoglycan) is freely accessible to the enzyme, contrary to that of gramnegative bacteria, which is shielded by the lipopolysaccharidic (LPS) layer of the outer membrane. These results agreed with Gul et al. (2015) who said that, Lysosyme is a protective enzyme, has antibacterial activity against grampositive. 
With using SAA and Hp alone as antibacterial agents in this study no significant inhibitory effect on the growth of Staphylococcus spp. under study was noticed and showed complete resistance to both them. This may be attributed to these strains need higher concentrations/or amount of SAA and Hp as the used strains showed very high antibiotic resistance. This was concluded by De Buck et al. (2016) who observed that the effects of SAA were dosedependent and, specific in-vivo biological effects of SAA really were dependent on the actual concentrations, whether in serum or in specific local microenvironments. On the other hand, Wanda (1997) reported that $\mathrm{Hp}$ has bacteriostatic effects by binding free haemoglobin, thus depriving bacteria from iron required for their growth and provide a novel microbicidal mechanism that may explain the mode of action of $\mathrm{Hp}$ in-vivo while in-vitro showed no antibacterial effect when used alone that may support our results.

In explanation of the mode of action of $\mathrm{Hp}$ as antibacterial agent, Davies et al. (2015) reported that, Hp's mechanism of action is sequestering iron, therefore, reducing the iron available for bacteria. Importantly, iron is crucial for bacterial growth, with a deficiency causing bacterial growth inhibition (Cherayil, 2011). Although iron is essential for most bacteria, the levels required and uptake mechanisms vary considerably between microorganisms. Generally, Gram-negative bacteria recognize iron sources via an outer membrane receptor. The iron is then transported into the cell by an ATP-binding cassette transporter within the inner membrane (Krewulak and Voge, 2008). Because Gram-positive bacteria lack an outer membrane, iron uptake mechanisms differ from that of the Gram-negative bacteria. The differences in iron uptake mechanisms are the likely reason $\mathrm{Hp}$ only demonstrated antibacterial properties against the Gram-negative bacteria examined.

Contrary to the present result that SAA hadn't antibacterial inhibitory action against Staphylococcus spp. under study; a study described a direct antibacterial activity of the SAA protein (Molenaar et al., 2009). This direct activity could be also participating in the reduction of the bacterial translocation observed in-vitro assay. SAA exerts antibacterial and antiviral activities by functioning as an opsonin for bacteria and by interfering with virus infection of host cells (Bucka et al., 2016). Chandrabala et al. (2006) demonstrated that SAA binds to a range of Gram negative bacteria including E.coli, K.pneumoniae, Sh.flexneri, V.cholerae, and P.aeruginosa through outer membrane protein A (OmpA) family members but not Gram-positive organisms such as S.pneumoniae and S.aureus which agreed with our results and may explain why SAA had no antibacterial effect on Staphylococcus spp. when used alone in the current work. Otherwise, Verginia et al. (2017) stated that SAA is one of the acute phase proteins (APPs) which has many highly linked genes (SAA1, SAA2, SAA3 and SAA4). Mammary SAA-3 had antibacterial activity (Schneider, 2015) and activates the involution via increasing cytokines related to innate immunity in cattle infected with $S$. aureus (Kalmus et al., 2013 and Domenech et al., 2014).

Antimicrobial peptides (AMPs) represent a vast array of molecules produced by virtually all living organisms as natural barriers against infection. Among AMP sources, an interesting class regards the food-derived bioactive agents including whey protein Lf (Bruni et al., 2016). In studying the antibacterial susceptibility of S.aureus and CNS isolated from the examined mammary gland tissues to antibiotics and/or their alternatives, the result revealed that, by using antibiotics alone bacteria under study showed multidrug resistance to the most used antibiotics especially S.aureus. Meanwhile synergistic effects were clearly observed by using mixtures of antibiotics and their alternatives as Lz, Lf, SAA and Hp. This is a novel technique for improve antibacterial effect of antibiotics or their alternatives as can be considered first step trying to use natural antibacterial substances. Bruni et al. (2016) explained the synergistic effects as the loss of inner membrane integrity may promote the uptake of other agents, for example antibiotics or other antibacterial peptides, leading to synergy with conventional antibiotics. In agreement with our results Lacasse et al. (2008) recommend that inframammary treatment with Lf was not satisfactory for overcoming beta-lactam resistant S.aureus infection. However, Lf coadministered with penicillin $\mathrm{G}$ increased the cure rate (from $12.5 \%$ to $33 \%$ ), reducing beta-lactamase activity in resistant S.aureus strains. The strong activity against mastitis pathogens of AMP and Lf in particular, has spurred interest in their potential application to the control of udder infections. In an in-vivo trial, Kawai et al. (2003) tested an infusion of Lf in cows affected by subclinical mastitis, caused by various bacteria, including E.coli and Staphylococci. Their results showed a significant reduction of bacteria in the mammary tissue already on day one after infusion and eradication of the disease after14 days.

Very little information for using SAA and Hp to improve the action of antibiotics especially for microorganisms that have multidrug resistance as $S$. aureus so this study may open the doors for more researches in these aspects to improve the control measures of mastitis and udder health in she camels or bovines.

Since the problem of mastitis is compounded by the incidence of subclinical mastitis which is a form of 
the disease where signs of inflammation (systemically and locally) are absent, Akerstedt et al. (2007). Consequently, an inability to readily recognise and diagnose animals with mastitis occurred, leading to a delay in treatment and control of infections thus allowing a possible spread to other uninfected quarters, (Funmilola et al., 2015). Thus, tests for indicators of inflammation can be used to screen quarters for intra-mammary inflammation (Pyörälä, 2003). In this investigation, we proposed that the major acute phase reactants (e.g. Lz, Lf, SAA and Hp) may be synthesized by the mammary gland tissue, and this came in agreement with previous studies of Close et al. (1997); Hsiang (2009); Berg et al. (2011) and Jiang et al. (2015). One of the aims of the on-going work was to study the effect of the isolated microorganisms on the levels (concentrations) of Lf, Lz, Hp and SAA in she-camel udder tissue samples that were affected with mastitis, and the results in (Table 5 and Fig.5) showed that the concentrations of the $\mathrm{Lz}, \mathrm{Hp}$ and SAA were significantly higher in tissue samples infected with both S.aureus and CNS when compared with the noninfected tissue samples. While the concentration of Lf showed a significant rise in tissue samples infected with CNS when compared with tissue samples infected with $S$. aureus. These findings came in agreement with Grönlund et al. (2003), who found that concentrations of $\mathrm{Hp}$ and SAA increased rapidly in both serum and milk during the acute phase of mastitis and a significant rise in milk concentrations of SAA were also found during chronic subclinical mastitis. They added that serum concentrations of SAA also tended to be higher during the chronic phase than pre-infection, and that increases in milk $\mathrm{Hp}$ and SAA were specific for the infected udder quarters. They concluded that, measurement of SAA in milk samples could be a useful tool in diagnosing mastitis. Similarly, Annamaria et al. (2016) found that, one in four milk samples where $S$. aureus was isolated had much lower Lf concentrations than the other three samples where Corynebacterium spp. and CNS.

Meanwhile, Bera et al. (2005) and Takahiro (2010) mentioned that Staphylococcus species belong to one of the few bacterial genera that are completely lysozyme resistant.

The characterisation of pathogenic Staphylococci especially isolates that showed resistance to antibiotics is important in combating of diseases caused by them. This was of a particular interest in the present study. It was desirable to characterise S.aureus isolates specially isolates that showed resistance for antibiotics. So, we used the onedimensional SDS-PAGE in studying protein profile of the isolates that showed resistance to antibiotics. The results revealed protein profiles containing (6-12 or more) discrete bands with molecular weights of
(16.95- 76.48) KDa. We compared the protein fingerprints of the protein bands of these isolates using the UPGMA clustering dendrogram analysis (Fig. 7 and Table 6). The results of the present dendrogram analysis illustrated that there were very weak or no similarities in protein profiles of the protein bands of the isolates ranging from 0 to 0.36 ; i.e approximately from 0 to $36 \%$ when converted to per cent values. This may be attributed to the different localities from which the samples were collected that may cause great difference in the protein profile of the isolates under this study. On the other hand, Fitzgerald et al. (2001) and Fábio et al. (2006) referred these weak similarities between the S.aureus strains to the extensive variation in gene content which may be caused by a change in the host environment, they also added that comparative genomic analysis of S.aureus strains revealed a high degree of inter-strain variation. The epidemic of toxic shock syndrome that occurred in the 1970s was caused by a change in the host environment, rather than rapid geographic dissemination of a new hypervirulent strain. DNA microarray analysis of large samples of clinically characterized strains provides broad insights into evolution, pathogenesis, and disease emergence.

Infectious Mastitis that caused by the bacterial harmful toxins that release in the udder and inducing lesions may vary from increased milk leukocytes counts with no gross changes in milk to increased vascular permeability or develop fibrosis or severe toxemia (Yousaf et al., 2010 and Ibrahim et al., 2011). In the present study, noticed histopathological changes in $S$. aureus isolated as single infection tissue sections revealed grossly, varied degrees of congestion and edema only two of them showed suppuration while most of the other cases showed fibrosis and paleness. On the other hand, microscopical examination exhibited variable histopathological changes which ranged from epithelial degeneration, congestion, coagulative necrosis and neutrophil infiltration, in the acute diffuse mastitis and sub-acute interstitial mastitis. On the other side alveolar atrophy, fibrosis with lymphocytic and histiocytic infiltration in chronic interstitial mastitis was the vast majority. Some cases showed disappearance of the alveolar lumen, through fibrosis to the complete destruction of the parenchyma. Similar observations were recorded in she camel by Hungerford (1989); Bakeer et al. (1994) and Abdurahman (1996).

Acute diffuse mastitis was attributed to E.coli infection. The inflammation mostly involved one quarter and caused destruction of the lining of the ducts, edema of interstitial tissues and infiltration of the acini with serous and inflammatory cells mainly neutrophils and macrophages. Similar findings were observed in she camel acute E.coli infection by 
Bakeer et al. (1994). It was also isolated from peracute mastitis in camels by Kapur et al. (1982); Quandal and Qudan (1984); Khan and Khan (2006) and Iyer et al. (2014). Marked leukocyte infiltration during mastitis was detrimental to the developing mammary parenchymal tissue which ultimately leading to milk loss (Nickerson, 2009 and Piepers et al., 2009). Whereas Barbour et al. (1985) and Karmy (1990) reported that, Streptococcus was a major cause of chronic mastitis in she camels. Those findings were in line with other previous studies (Kheira and Abdellatif, 2014 and Zeleke, 2016) in Ethiopia. According to Hussai et al. (2012c) the tissue sections from mastitic animals revealed mild, moderate or severe atrophy of alveoli with cellular exudate in the lumen of the alveoli. The existence of acute and chronic inflammation in mammary parenchymal tissues was confirmed and fibrous tissue proliferation was seen in the mammary gland.

Moreover, lesions of the mammary tissue reduce the number and activity of epithelial cells and therefore contributes to lower milk production with increasing proportions of lymphocytes and macrophages was reported by Zhao and Lacasse (2008), multiple inflammatory cell types and structural damage in the S.aureus group, similar results observed in previous research- $\alpha$, IL- 6 and IL-1 $\beta$ play important roles in the inflammatory response. TNF- $\alpha$ is an early cytokine, which plays a critical role in the cascade of other proinflammatory cytokines and inflammatory mediators. IL-1 $\beta$ which is considered to be a gatekeeper of inflammation plays an essential part in the early inflammatory response. Pathological changes occurred in udder tissue could be due to severe tissue damage caused by different mastitis pathogens.

Alkaline phosphatase, a membrane-associated glycoprotein enzyme, increases hydrolysis of phosphates and is located mainly on the outer cellular membranes of tissues having vigorous transport processes (Murray and Ewen, 1992). Milk protein synthesis in mammary tissue is a complex mechanism under the influence of local and systemic hormones along with some other factors those affect milk yield (Khaliq and Rahman, 2010 and Hussain et al., 2010). The weak AP activity and protein density that observed in this work in singly isolated S.aureus mastitic tissue sections were observed previously by Hassan (2004); Silanikove (2008); El-Sayed et al. (2009); Hussain et al. (2012c) and Hussain et al. (2013) which attributed to the degenerative changes of mammary epithelium with connective tissue proliferation and impaired activity of endoplasmic reticulum that induced by microbial agents. These degenerated mammary cells encompassing the active cellular protein was substituted by the spread of connective tissue under the bacterial toxins effect which resulted in poor biosynthetic capacity of udder and decreases cellular differentiation. As well as may be related with deactivation of this enzyme owing to negative regulatory process of mammary gland, also could be due to impaired milk secretory mechanism (El-Sayed et al., 2009; Hussain et al., 2012c and Hussain et al., 2013).

Regarding to the Morphometric investigations of tissue sections from singly infected S. aureus comparable to non mastitic showed significant decrease $(\mathrm{P} \leq 0.05)$ in alveolar diameter, number of alveoli and alveolar cell population whereas the interstitial connective tissues showed significant increase $(\mathrm{P} \leq 0.05)$. These results indicated severe tissue degenerative changes and damage due to different mastitis pathogens. However, the decrease number of alveoli, luminal area and less number of alveolar secretary cells has been determined in advance stage of lactation (Akers et al., 2006). In addition, the decreased number of alveolar secretory cell could be due to cell death induced by milk accumulation in alveoli (Singh et al., 2005). The number of secretory cells per alveolus was the best indicator of mammary gland lactogenic activity (ElSayed et al., 2009; EL-Sayed et al., 2013 and Hussain et al., 2013).

\section{CONCLUSION}

We concluded that, Staphylococci were the major bacteria causing mastitis in she camels and showed great differences in their protein profiles, consequently caused significant increase in the inflammatory responses of the udder tissues represented by the increase of Lz, Lf, SAA and Hp concentrations in the tissues. Staphylococci as single infection enough for inducing sever degenerative changes and damage that reflecting impaired activity as well as printed on the different histopathological, histochemical and morphometric changes in she camels mammary parenchyma. Furthermore, this study offers opportunities for development of treatment strategies that may eliminate or even reduce mammary tissue damage caused by Staphylococcal mastitis with or without the use of antibiotics and/or anti-inflammatory molecules like Lz, Lf, SAA and Hp.

\section{REFERENCES}

Abdelgadir, A.E. (2014): Mastitis in camels (Camelus dromedaries): Past and recent research in pastoral production system of both East Africa and Middle East. J. Vet. Med. Anim. Health. 6 (7): 208-216.

Abdurahman, O.A.S. (1996): The detection of subclinical mastitis in the bacterian camel (Camelus bactrians) by somatic cell count and California mastitis test. Vet. Res. Comm., 20 (1): 9-14. 
Abeer, A.M.; Zakia, A.M.; Muna, E.A. and Sabie, Y.A. (2016): Bacteriological and pathological studies of mammary glands affections in camels (Camelus dromedarius) at Tumbool abattoir, Sudan. Brit. Microbiol. Res. J., 15(5): $1-8$.

Abrhaleya, A. and Leta, S. (2018): Medicinal value of camel milk and meat. J. Appl. Anim. Res., 46(1):552-558.

Akers, R.M.; Capuco, A.V. and Keys, J.E. (2006): Mammary histology and alveolar cell differentiation during late gestation and early lactation in mammary tissue of beef and dairy heifers. Livest. Sci., 105:44-49.

Akerstedt, M.; Waller, K.P. and Sternesjo, A. (2007): Haptoglobin and serum amyloid $\mathrm{A}$ in relation to the somatic cell count in quarter, cow composite and bulk tank milk samples. J. Dairy Res., 74:198-203

Alamin, M.A; Alqurashi, A.M; Elsheikh, A.S. and Yasin, T.E (2013): Mastitis incidence and bacterial causative agents isolated from lactating she-camel (Camelus Dromedaries). J. Agricul. Vet. Sci., 2 (3): 7-10.

Al-Juboori, A.A.; Kamat, N.K. and Sindhu, J.I. (2013): Prevalence of some mastitis causes in dromedary camels in Abu Dhabi, United Arab Emirates. Iraqi J. Vet. Sci., 27(1): 9-14.

Alluwaimi, A.M.; Salem, K.T.A.; Al-Ashqar, R.A. and Al-shubaith, I.H. (2017): The Camel's (Camelus Dromedarius) mammary gland immune system in health and disease. J. Adv. Dairy Res., 5 (1):6p.

Al-Majali, A.M.; Ismail, Z.B.; Al-Hami, Y. and Nour, A.Y. (2007): Lactoferrin concentration in milk from camela milk (Camelus dromedarius) with and without sub-clinical mastitis. Int. J. Appl. Res. Vet. Med., 5(3): 120-124.

Al-Otaibi, M.M. and El-Demerdash, H. (2013): Nutritive value and characterization properties of fermented camel milk fortified with some date palm products chemical, bacteriological and sensory properties. Int. J. Nut. Food Sci., 2(4):174-180.

Amany, S.; Mahmoud, A. and, Ahmed, M. (2005): Anti-schistosomal activity of colostral and mature camel milk on Schistosoma mansoni infected mice. Asia Pac. J. Clin. Nutr., 14(4):432-438.

Annamaria, L.G.; Miodrag, Ž.R.; Stanko, F.; Marija, J.P.; Sara, S.S. and Dubravka, S. M. (2016): Lactoferrin concentrations in bovine milk during involution of the mammary glands, with different bacteriological findings. Veterinarski Arhiv., 86 (4): 487-497.

Aqib, A.I.; Ijaz, M.; Hussain, R.; Durrani, A.Z.; Anjum, A.A.; Rizwan, A.; Sana, S.; Farooqi, S.H. and Hussain, K. (2017): Identification of coagulase gene in Staphylococcus aureus isolates recovered from subclinical mastitis in camels. Pak. Vet. J., 37(2): 160-164

Attia, H.; Kherouatou, N. and Dhouib, A. (2001): Dromedary milk lactic acid fermentation: microbiological and rheological characteristics. J. Indus. Microbiol. Biotechnol., 26: 263-270.

Bakeer, A.M.; Afify, M.; El Jakee, J. and Hemeda, M. (1994): Pathological and bacteriological studies on mammary gland affections in one humped she camel. Vet. Med. J. Giza. (B): 321-326.

Barbour, E.K.; Nabbut, N.H.; Frerichs, W.M.; Al Nakhli H.M. and Mukayel, A.A. (1985): Mastitis in Camelus dromedaries in Saudi Arabia. Trop. Anim. Hlth. Prod., 17 (3): 173 179.

Benkerroum, N. (2008): Antimicrobial activity of lysozyme with special relevance to milk. African J. Biotech., 7 (25):4856-4867.

Bera, A.; Herbert, S.; Jakob, A.; Vollmer, W. and Götz, F. (2005): Why are pathogenic staphylococci so lysozyme resistant? The peptidoglycan O-acetyltransferase OatA is the major determinant for lysozyme resistance of Staphylococcus aureus. Mol. Microbiol., 55(3):778-87.

Berg, L.C.; Thomsen, P.D.; Andersen, P.H.; Jensen, H.E. and Jacobsen, S. (2011): Serum amyloid A is expressed in histologically normal tissues from horses and cattle. Vet. Immunol. Immunopathol., 15;144(1-2):155-9.

Chandrabala, S.; Ranjeeta, H.D. and Raynes, J.G. (2006): Serum amyloid A is an innate immune opsonin for Gram-negative bacteria. Blood. 108(5):1751-1757.

Cherayil, B.J. (2011): The role of iron in the immune response to bacterial infection. Immunol. Res., 50:1-9.

Close, M.J.; Howlett, A.R.; Roskelley, C.D.; Desprez, P.Y.; Bailey, N.; Rowning, B.; Teng, C.T.; Stampfer, M.R. and Yaswen, P. (1997): Lactoferrin expression in mammary epithelial cells is mediated by changes in cell shape and actin cytoskeleton. J. Cell Sci., 110 (22): 286171.

Conesa, C.; Sanchez, L.; Rota, C.; Perez, M.; Calvo, M.; Farnaud, S. and Evans, R.W. (2008): Isolation of lactoferrin from milk of different species: calorimetric and antimicrobial studies. Comp. Biochem. Physiol., 150:131-139.

Davies, E.B.; Moses, R.; Sloan, A.; Stephens, P. and Davies, L.C. (2015): Oral mucosal lamina propria-progenitor cells exert antibacterial properties via the secretion of osteoprotegerin and haptoglobin. Stem cells Transl. Med., 4(11): 1283-1293.

De Buck, M.; Gouwy, M.; Wang, J.M.; Van Snick, J.; Opdenakker, G.; Struyf, S. and Van Damme, J. (2016): Structure and expression of different serum amyloid A (SAA) variants and their 
concentration-dependent functions during host insults. Current Med. Chem., 23: 1725-1755.

Dignam, J. D. (1990): Preparation of extracts from higher eukaryotes. Methods Enzymol., 182: 194-203.

Domenech, A.; Pares, S. and Bach, A.A. (2014): Mammary serum amyloid A3 activates involution of the mammary gland in dairy cows. J. Dairy Sci., 97: 7595-7605.

Durzýnska, J.; Przysiecka, L.; Nawrot, R.; Barylski, J.; Nowicki, G.; Warowicka, A.; Musidlak, O. and Gózdzicka-Józefiak, A. (2015): Viral and other cell-penetrating peptides as vectors of therapeutic agents in medicine. J. Pharmacol. Exp. Ther., 354: 32-42.

El-Agamy, E.I.M.; Nawar, S.M.S.; Awad, S. and Haenlein, G.F.W. (2009): Are camel milk proteins convenient to the nutrition of cow milk allergic children. Small Rum. Res., 82 (1): 1-6.

Elsayed, E.H.; EL-Shafie, M.H.; Saifelnasr, E.O.H. and Abu El-Ella, A.A. (2009): Histological and histochemical study on mammary gland of Damascus goats through stages of lactation. Small Rum. Res., 85:11-17.

EL-Sayed, H.E.; Saifelnasr, E.O.H. and Ashmawy, T.A.M. (2013): Effects of milking frequency on milk production and histological structure of udder in Zaraibi dairy goats. Egyptian J. Sheep \& Goat Sci., 8 (2): 47- 59.

Fábio, A.A.; Fred, M.; Octavio, F.; Rossiane Maria, G.P.; Françoise, P.R. and Lee, W.R. (2006): New Staphylococcus aureus genotyping method based on exotoxin (set) genes. J.Clin.Microbiol., 44(8): 2728-2732.

Farnaud, S.; Spiller, C.; Moriarty, L.C.; Patel, A.; Gant, V.; Odell E.W. and Evans, R.W. (2004): Interactions of lactoferricin-derived peptides with LPS and antimicrobial activity. FEMS microbial. let., 233 (2): 193-199.

Fitzgerald, J.R. and Musser, J.M. (2001): Evolutionary genomics of pathogenic bacteria. Trends Microbiol., 9(11):547-53.

Foster, T.J.; Geoghegan, J.A.; Ganesh, V.K. and Hook, M. (2014): Adhesion, invasion and evasion: The many functions of the surface proteins of Staphylococcus aureus. Nat. Rev. Microbiol., 12(1):49-62.

Funmilola, C.T.; Mary, W.; Peter, H.; Timothy, P.; Hayley, H. and Peter D. E (2015): The major acute phase proteins of bovine milk in a commercial dairy herd. BMC Vet. Res., 11: 207.

Gill, E.E.; Franco, O.L. and Hancock, R.E.W. (2015): Antibiotic adjuvants: Diverse strategies for controlling drug-resistant pathogens. Chem. Biol. Drug. Des., 85:56-78.

Gizachew, A.; Teha, J. and Birhanu, T. (2014): Review on medicinal and nutritional values of camel milk. Nat. Sci., 12(12):35-40.
Grönlund, U.; Hultén, C.; Eckersall, P.D.; Hogarth, C. and Persson, W.K. (2003): Haptoglobin and serum amyloid A in milk and serum during acute and chronic experimentally induced Staphylococcus aureus mastitis. J. Dairy Res., 70(4):379-86.

Gul, W.; Farook, N.; Anees, D.; Khan, U. and Rehan, F. (2015): Camel milk: a boon to mankind. Int. J. Res. Stud. Biosci., 3:23-29.

Hany, A.H.; Khaled, A.; Alaa, M.G.; Mohamed, K.E.; Khaled, A.A. and Hosein, H.I. (2018): Milk amyloid $\mathrm{A}$ as a biomarker for diagnosis of subclinical mastitis in cattle. Vet. World. 11(1): 34-41.

Hassan, L.R. (2004): Histochemical assessment of mammary gland capacity pertaining to milk production in buffaloes. Egyptian J. Anim. Prod., 41: 309-320.

Hegazy, A.A.; El Dughaym, A.; Alaknah, M.; Housawi, F.M.T. and Hatem, M.E. (2004): Studies on mastitis in female camel with special reference to brucellosis J. Camel Science., 1: 96-102.

Hungerford, T.G. (1989): Diseases of Livestock. $8^{\text {th }}$ ed. Mcgraw Hill Book Comp, Sydney.

Husein, A.; Haftu, B.; Hunde, A. and Tesfaye, A. (2013): Prevalence of camel (Camelus dromedaries) mastitis in Jijiga Town, Ethiopia. African J. Agric. Res., 8(24): 3113-3120.

Hussain, R.; Khan, A.; Javed, M.T. and Ali, F. (2013): Morphometric and pathological studies on mammary gland of slaughtered Nili-Ravi buffaloes. Pak. J. Agri. Sci., 50(1): 123-130.

Hussain, R.; Javed, M.T.; Khan, A.; Mahmood, F. and Kausar, R. (2012c): Mastitis and associated histo-pathological consequences in the context of udder morphology. Int. J. Agric. Biol. 14:947-952.

Hussain, M.; Ghafoor, A. and Saboor, A. (2010): Factors affecting milk production in buffaloes: a case study. Pakistan Vet. J., 30: 115-117.

Ibrahim, M.A.R. (2008): Camel reproduction and production in Egypt WBC / ICAR Satellite Meeting On Camelid Reproduction12-13 July, , Budapest, Hungary Program and Extended Abstracts.

Iyer, A.P.; Albaik, M. and Baghallab, I. (2014): Mastitis in camels in African and Middle East countries. J. Bacteriol. Parasitol., 5(3): 188.

Jiang, M.F.; Hu, M.J.; Ren, H.H. and Wang, L. (2015): Molecular cloning and characterization of a new C-type lysozyme gene from Yak mammary tissue. Asian-Aust. J. Anim. Sci.; 28(12):1774-83.

Kalmus, P.; Simojoki, H.; Pyorala, S.; Taponen, S. and Holopainen, J. (2013): Milk haptoglobin, milk amyloid $\mathrm{A}$, and N-acetyl-beta-Dglucosaminidase activity in bovines with naturally occurring clinical mastitis diagnosed 
with a quantitative PCR test. J. Dairy Sci., 96: 3662-3670.

Kappeler, S.R.; Ackermann, M.; Farah, Z. and Puhan, Z. (1999): Sequence analysis of camel (Camelus dromedarius) lactoferrin, Int. dairy J., 9(7): 481-486.

Kapur, M.P.; Khanna, B.M. and Singh, R.P. (1982): A peracute case of mastitis associated with Klebsiella pneumaniae and Escherichia coli. Indian Vet. J., 59: 650-651.

Karmy, S.A. (1990): Bacteriological studies on mastitis in small ruminants and she camel in upper Egypt. J. Egyptian Vet. Med. Assoc., 50: 69-79.

Kawai, K.; Nagahata, H.; Lee, N.Y.; Anri, A. and Shimazaki, K. (2003): Effect of infusing lactoferrin hydrolysate into bovine mammary glands with subclinical mastitis. Vet. Res. Commun., 27: 539-548.

Khaliq, T. and Rahman, Z.U. (2010): Haematological studies of Nili-Ravi buffaloes injected with recombinant bovine somatotropin. Pakistan Vet. J., 30: 53-57.

Khan, M. and Khan, A. (2006): Basic facts of mastitis in dairy animals: A review. Pakistan Vet. J., 26(4): 204-208.

Kheira, G. and Abdellatif, N. (2014): Impact of subclinical mastitis on the health of the mammary gland. Global Veterinaria. 12 (2): 193-196.

Koneman, W.K.; Allen, S.D.; Janda, W.M.; Schreckenberger, P.C.; Propcop, G.W.; Woods, G.L. and Winn, W.C. (2005): Color Atlas and Textbook of Diagnostic Microbiology, $6^{\text {th }}$ ed. Lippincott-Raven Publisher, Philadelphia, USA.

Krewulak, K.D. and Vogel, H.J. (2008): Structural biology of bacterial iron uptake. Biochim.Biophys.Acta., 1778:1781-1804.

Lacasse, P.; Lauzon, K.; Diarra, M.S. and Petitclerc, D. (2008): Utilization of lactoferrin to fight antibiotic-resistant mammary gland pathogens. J. Anim. Sci., 86 (13): 66-71.

Laemmli, U.K. (1970): Cleavage of structural proteins during the assembly of head of bacteriophage T4. Nature 227:680- 68.

Laxminarayan, R.; Duse, A.; Wattal, C.; Zaidi, A.K.M.; Wertheim, H.F.L.; Sumpradit, N.; Vlieghe, E.; Hara, G.L.; Gould, I.M. and Goossens, H. (2013): Antibiotic resistance-the need for global solutions. Lancet Infect. Dis., 13: $1057-1098$

Masschalck, B. and Michiels, C.W. (2003): Antimicrobial properties of lysozyme in relation to foodborne vegetative bacteria. Critical rev. Microbiol., 29 (3):191-214.

Middleton, J.R. (2013): Staphylococcus aureus mastitis: Have we learned anything in the last 50 years? NMC Regional Meeting Proceedings.
Molenaar, A.J.; Harris, D.; Rajan, G.H.; Pearson, M.L.; Callaghan, M.R. and Sommer, L. (2009): The acute-phase protein serum amyloid A3 is expressed in the bovine mammary gland and plays a role in host defence. Biomarkers 14:2637.

Mona, E.; Ragia, O.; Abeer, A. and Mosa, T. (2010): Biochemical effects of fermented camel milk on diarrhea in rats. N Y Sci. J., 3(5):106-111.

Murray, G.I. and Ewen, S.W. (1992): A new fluorescence method for alkaline phosphatase histochemistry. J. Histochem. Cytochem., 40: 1971-1978.

National Committee for Clinical Laboratory Standards (2008): Performance standards for antimicrobial disk and dilution susceptibility tests for bacteria isolated from animals; Approved Standard, 2nd Edn. NCCLS Document M31- A3.Wayne, PA: National Committee for Clinical Laboratory standard.

Niaz, B.; Zahoor, T.; Randhawa, M.A. and Jamil, A. (2017): Isolation of lactoferrin from camel milk through fast protein liquid chromatography and its antagonistic activity against Escherichia coli and Staphylococcus aureus. Pakistan J. Zool., 49(4):1307-1313.

Nickerson, S.C. (2009): Control of heifer mastitis: antimicrobial treatment-an overview. Vet Microbiol., 134: 128-35.

Piepers, S.; De Vliegher, S.; de Kruif, A.; Opsomer, G. and Barkema, H.W. (2009): Impact of intramammary infections in dairy heifers on future udder health, milk production, and culling. Vet. Microbiol., 134: 113-120.

Pyörälä, S. (2003): Indicators of inflammation in the diagnosis of mastitis. Vet. Res., 34: 565-578.

Qayyum, A.; Khan, A.; Hussain, R.; Avais, M.; Nisar, A.; Ahrar, K. and Khan, M.S. (2016): Prevalence and association of possible risk factors with sub-clinical mastitis in cholistani cattle. Pakistan J. Zool., 48(2): 519-525.

Quandal, S.S. and Qudan, J. (1984): Bacteriological study of some cases of mastitis in the dromedary (Camelus dromedaries) in UAE (Prelimenary report). Rev. D"elev. Med. Vet. Paystrop., 135: 705-707.

Quinn, P.J.; Markey, B.K.; Leonard, F.C.; FitzPatrick, E.S.; Fanning, S. and Hartigan, P.J. (2011): Veterinary Microbiology and Microbial Disease. $2^{\text {nd }}$ ed., Wiley-Blackwell, J Wiley and Sons Ltd Publication, UK.

Rabab, M.M. (2009): Inhibition effect of camel milk immune proteins against some mastitis-causing bacteria. BTAI.J., 3(1): 30-34.

Salama, M.A.; Alaa B.I.; Manal, B.M. and AbdelKader, A.E. (2013): Development of new strategy for non-antibiotic therapy: Bovine lactoferrin has a potent antimicrobial and immunomodulator effects. Adv. Infect. Dis., 3:185-192. 
Schneider, A. (2015): Acute phase proteins for diagnosis of diseases in dairy cattle. Vet. J., 205: 333-334

Sears, P.M. and McCarthy, K.K. (2003): Management and treatment of staphylococcal mastitis. Vet. Clin. North. Am. Food. Anim. Pract., 19: 171-185.

Shabo, Y.; Barzel, R.; Margoulis, M. and Yagil, R. (2005): Camel milk for food allergies in children. Israel Med. Association J., 7:796-8.

Sendecor, G.W. and Cochran, W.G. (1989): Iowa s Statistical methods. 7th.ed tate Univ. press. Ames, Iowa.

Shakir, K.; Walsh, M.K. and Mohammed, S.A. (2013): Characterization of Iraqi sheep milk lysozyme with respect to molecular weight and hydrolytic activity. Dairy Sci. \& Technol., 93:699-705

Silanikove, N. (2008): Milk lipoprotein membranes and their imperative enzymes. Adv. Exp. Med. Biol. 606:143-161.

Singh, K.; Dobson, J.; Phyn, C.V.C.; Davis, S.R.; Farr, V.C.; Molenaar, A.J. and Stelwagen, K. (2005): Milk accumulation decreases expression of genes involved in cellextracellular matrix communication and is associated with induction of apoptosis in the bovine mammary gland. Livest. Prod. Sci., 98:67-78.

Suvarna, K.S.; Layton, C. and Bancroft, J.D. (2013): Bancroft's Theory and Practice of Histological Techniques, by Suvarna, 7th Edition Churchill Livingstone.

Takahiro, S.B. G.P.; Andrea, J.W.; Constantinos, B.; Helen, S.G.; Courtney, A.B.; Christopher, N.R.; Edward, A.M.; Alan, A.; Friedrich, G.; George, Y. and David, M. U.(2010): Staphylococcus aureus evades the lysozymebased digestion of peptidoglycan that links phagocytosis and macrophage IL-1 $\beta$ secretion. Cell Host Microbe. 21; 7(1): 38.

Tiwari, J.G.; Babra, C.; Tiwari, H.K.; Williams, V.; Wet, S.D. and Gibson, J. (2013): Trends in therapeutic and prevention strategies for management of bovine mastitis: An overview. J. Vaccines Vaccin., 4:1-11.

Tuasikal, B.J.; Wibawan, L.W.T.; Pasaribu, F.H. and Estuningsih, S. (2012): Bacterial protein characterization of Streptococcus agalactiae by SDS-Page method for subclinical mastitis irradiated vaccine materials in dairy cattle. Atom Indonesia. 38 (2).

Verginia, M.E.F.; Amany, M.A.; Nermin, A.I.; Samar, M.A. and Mohamed, A.E. (2017): Serum amyloid A4 and Ceruloplasmin evaluated mastitic cattle with Escherichia coli or Staphylococcus aureus including resistant genes. J. Bioanal. Biomed., 9(3): 132-136.

Wanda, D. (1997): Biological Functions of Haptoglobin - New Pieces to an Old Puzzle. Eur J Clin.ChemClin. Biochem., 35(9):647654.

Wang, G.; Li, X. and Wang, Z. APD2 (2009): The updated antimicrobial peptide database and its application in peptidedesign. Nucleic Acids Res., 37 (1): 933-937.

Wassell, J. (2000): Haptoglobin: function and polymorphism. Clin. Lab., 46 (11-12):547-52.

Woubit, S.; Bayleyegn, M.; Bonnet, P. and JeanBaptiste, S. (2001): Revue Élev. Méd. vét. Pays trop., 54 (3-4): 207-212.

Yousaf, M.; Muhammad, G.; Khan, M.Z. and Rahman, S.U. (2010): Effect of infusions of non-antibiotic anti bacterials alone and in combination with Cephradine on milk yield of buffaloes affected with clinical mastitis. Pakistan Vet. J., 30: 39-43.

Zeleke, M.M. (2016): Morphometrical, pathological and bacteriological study of mammary gland of cows with subclinical and clinical mastitis in selected farms and abattoirs in central Ethiopia Addis Ababa. A thesis submitted to the college of veterinary medicine and agriculture of Addis Ababa university in partial fulfilment of the requirements for the degree of master of science in veterinary pathology.

Zhao, X. and Lacasse P. (2008): Mammary tissue damage during bovine mastitis: causes and control. J. Anim. Sci., 86(13):57-65. 


\section{دراسات هستومورفومتريه ومناعيه علي الميكروب العنقودى المسبب لإلتهاب الضرع في إناث الجمال ودراسة تأثير

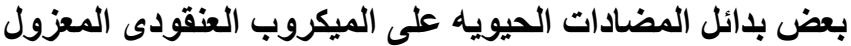

هناء على حسن الحلوانى ، هناء عبد المنعم عبد الفتاح عصفور ، إيناس محمد جمال اللين ، شيرين سمير الهرنس

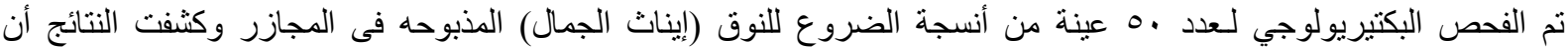

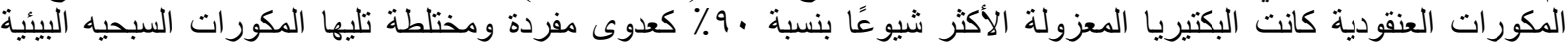

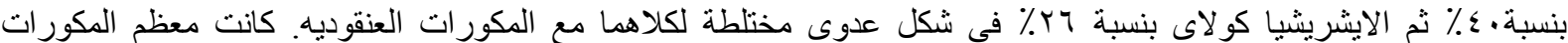

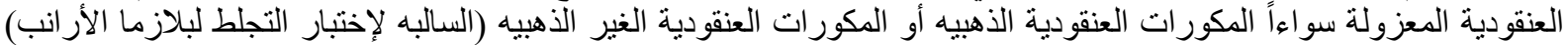

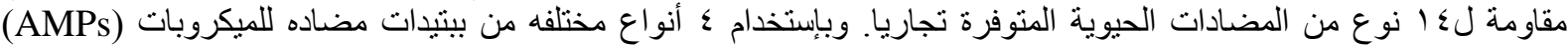

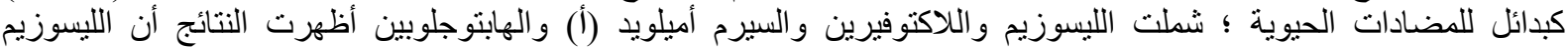

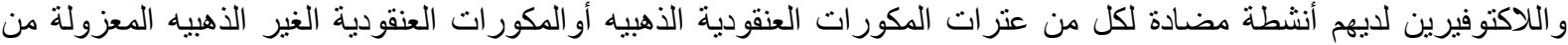

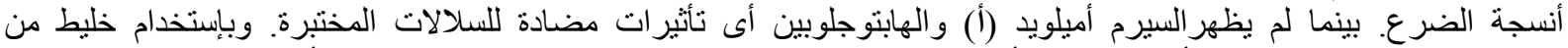

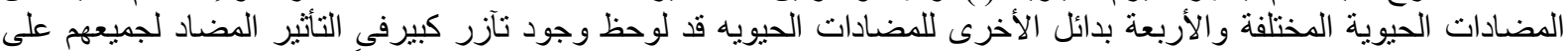

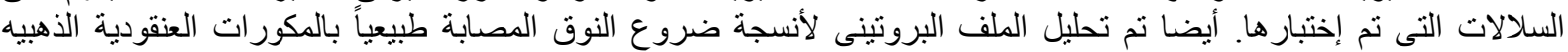

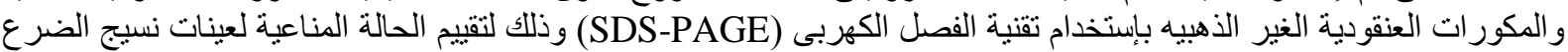

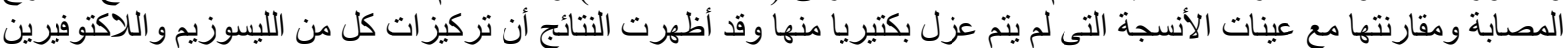

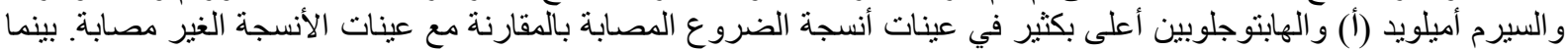

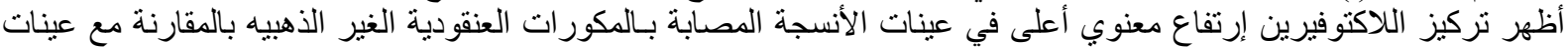

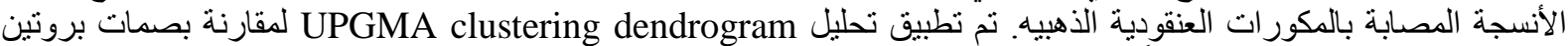

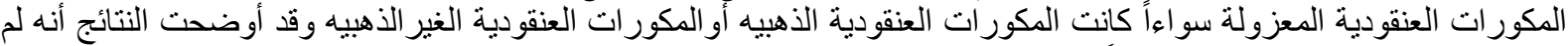

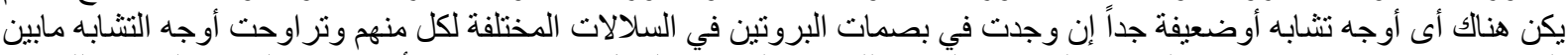

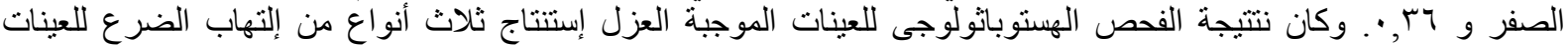

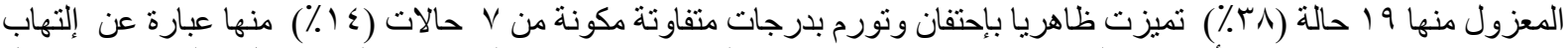

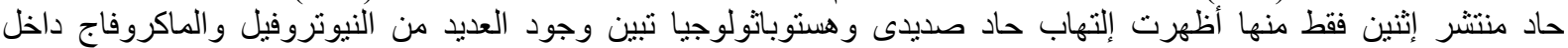

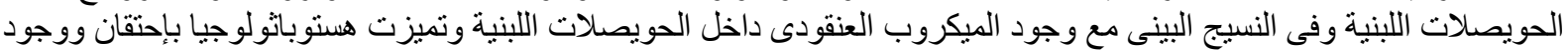

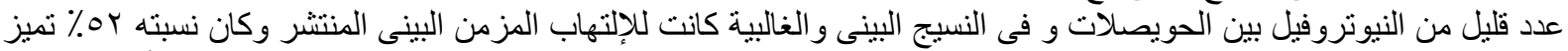

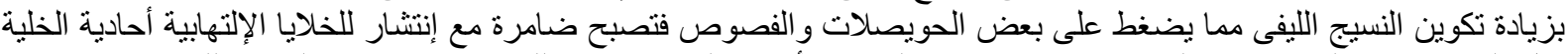

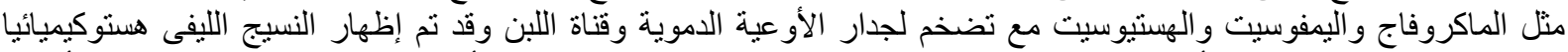

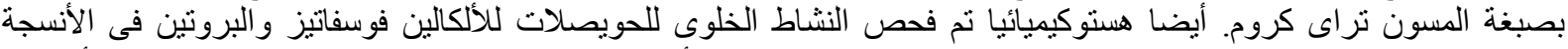

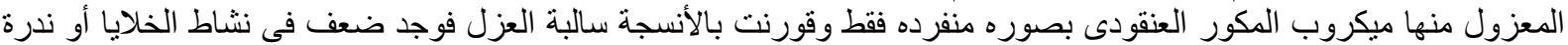

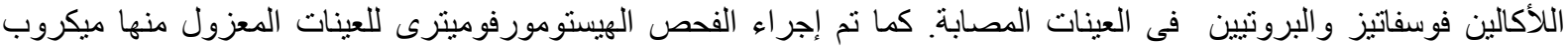

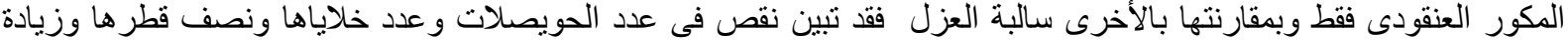

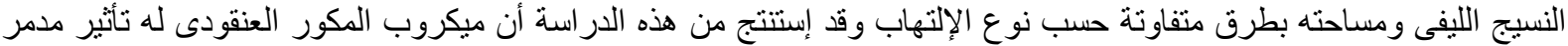

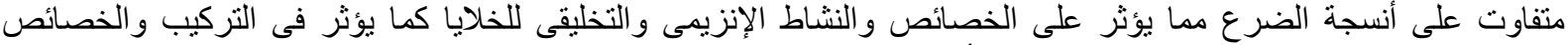

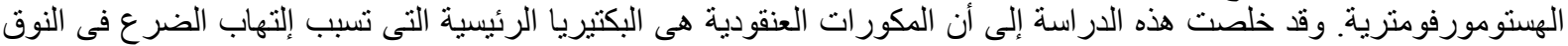

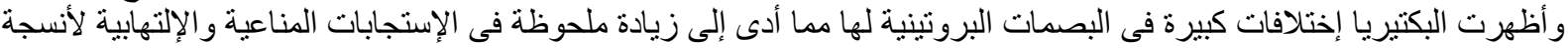

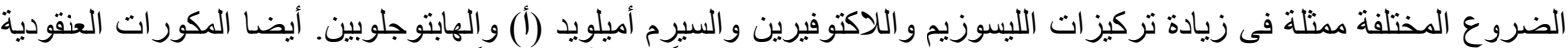

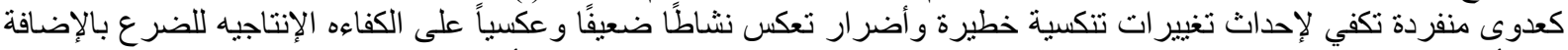

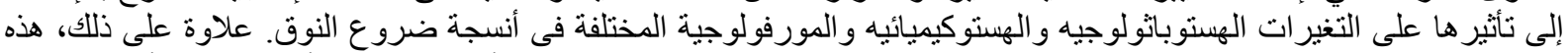

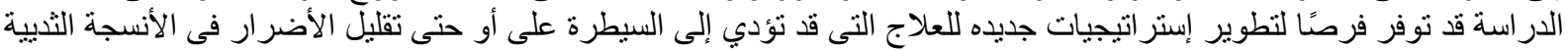

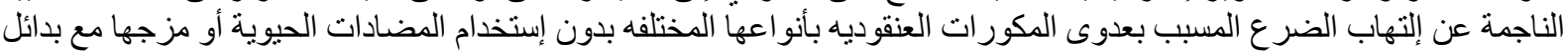

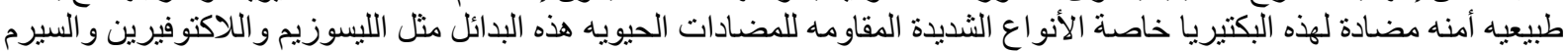

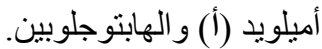

